\title{
A Zona Tectônica Teixeira Terra Nova - ZTTTN - Fundamentos da Geologia Regional e Isotópica
}

\author{
Benjamim Bley de Brito Neves' (bbleybn@usp.br), William Randall Van Schmus², \\ Marianne Kozuch2 ${ }^{2}$ Edilton José dos Santos ${ }^{3}$, Liliane Petronilho ${ }^{4}$ \\ 'Departamento de Mineralogia e Geotectônica - Instituto de Geociências - USP \\ R. do Lago 562, CEP 05508-080, São Paulo, SP, BRA \\ ${ }^{2}$ Department of Geology - University of Kansas, Lawrence, Kansas, USA \\ ${ }^{3}$ Serviço Geológico do Brasil - CPRM, Rio de Janeiro, RJ, BRA \\ ${ }^{4}$ Centro de Pesquisas Geocronológicas - Instituto de Geociências - USP, São Paulo, SP, BRA
}

Recebido em 22 de dezembro de 2004; aceito em 16 de junho de 2005

Palavras-chave: Província Borborema, Zona Transversal, Terreno Alto Pajeú, Terreno Riacho Gravatá, Brasiliano, granitos neoproterozóicos.

\section{RESUMO}

Uma zona tectônica linear, de forma sigmoidal, ocorre de Teixeira (Paraíba, ao norte-nordeste) a Terra Nova (Pernambuco, ao sul-sudoeste), com disposição diagonal ao domínio da Zona Transversal - ZT, que é a porção central da Província Borborema, de forma a subdividir a ZT em dois domínios lito-estruturais e geotectônicos distintos. Para norte e noroeste ficam os terrenos do Riacho Gravatá - RG (Eoneoproterozóico) e Piancó-Alto Brígida-PAB (Neoproterozóico), caracterizados por baixo grau de metamorfismo. Para o sul e sudeste fica o terreno Alto Pajeú (TAP, Eoneoproterozóico, ortognaisses e rochas supracrustais mesozonais) e seu embasamento, terreno Alto Moxotó - TAM (Paleoproterozóico), de grau médio a elevado de metamorfismo. Esta zona linear ou "alto" constituído de ortognaisses (do TAP e do embasamento paleoproterozóico que aflora esparsamente) é perlongado e marcado por uma série quase contínua de rochas intrusivas, plutões e stocks graníticos variados e sieníticos do tempo Ediacarano (idades entre 630 e $570 \mathrm{Ma}$, principalmente). Na história evolutiva desta porção linear particularmente soerguida do Planalto da Borborema há o registro (direto e/ou indireto) de eventos geológicos policíclicos, do Paleoproterozóico, do Eoneoproterozóico, do Ediacarano, do Eocambriano e do Cenozóico (sedimentação correlativa, elaboração de crostas e soerguimento regional), com implicações interessantes na geografia e sócio-economia regional. No presente trabalho será dada ênfase aos dados isotópicos (métodos $\mathrm{Rb}-\mathrm{Sr}, \mathrm{Sm}-\mathrm{Nd}$ sobretudo) desta zona diferenciada, e nos contextos por ela separados, assim como no seu papel dentro do contexto tectônico regional, usufruindo para isto de expressivo acervo de dados geológicos e isotópicos, obtidos na última década (grande parte do qual ainda inédita). Além disso, hipóteses interpretativas serão postuladas para esta linha axial tectônica que subdivide a Zona Transversal em domínios geológicos distintos, considerando-a como conseqüência e subproduto de três processos paralelos de subducção no Neoproterozóico.

Keywords: Borborema Province, Transversal Zone, Alto Pajeú Terrane, Riacho Gravatá Terrane, Brasiliano, Neoproterozoic granites.

\section{ABSTRACT}

A sigmoidal-shape linear tectonic zone occurs from Teixeira (Paraíba, to the north-northeast)- to Terra Nova (Pernambuco, to the south-southwest) as a line diagonal to the "Transversal Zone", which is the central tectonic portion of the Borborema Province, thus dividing this province into two different litho-structural and tectonic domains. To the north and northwest occur the Early Neoproterozoic Riacho Gravatá (RG) and the Neoproterozoic Piancó-Alto Brígida (PAB) terranes, both of them characterized by supracrustal rocks with low-grade of regional metamorphism. To the south-southwest occur the Alto Pajeú terrane (TAP, Early Neoproterozoic, orthognaisses and mesozonal supracrustal rocks) and the domain of its basement, the Alto Moxotó terrane (TAM, Paleoproterozoic in age), with high grade metamorphic rocks. This proposed "tectonic 
zone" is mostly composed by orthogneisses (from TAP and its Paleoproterozoic basement) pierced by an almost continuous series of intrusive granitic and syenitic rocks (plutons and stocks) of the Ediacaran period (ages between 630 and $570 \mathrm{Ma}$ ). During the evolutionary history of this linear portion of the plateau of the Borborema province there are some (direct and indirect) records of polycyclic geologic events of the Paleoproterozoic, Early Neoproterozoic, Ediacaran, Cambrian and Cenozoic era (a sedimentary veneer, evolution of a supergenic crust and regional uplift) with interesting implications for the regional geology, geography and social-economic development. In this paper the emphasis will be given to the isotopic data ( $\mathrm{Rb}-\mathrm{Sr}, \mathrm{Sm}-\mathrm{Nd}$, mostly) along this special zone and the domains that it separates, as well its role on the regional tectonic framework. For this purpose, we take into consideration an expressive amount of available geological and isotopic data, obtained along the last decade (most of them not published) from different sources. Additionally, some first interpretative hypotheses will be postulated, where this tectonic zone (ZTTTN) would be formed as by-product of three parallel Neoproterozoic subduction zones.

\section{INTRODUÇÃO}

A Província Borborema (Almeida et al., 1981) está situada na porção nordeste oriental da América do Sul, apresenta evolução proterozóica, com história e consolidação culminando no Ciclo Brasiliano. Esta província é costumeira e naturalmente subdividida em três distintos domínios (Santos et al., 1997; Brito Neves et al., 2000; entre outros): setentrional, zona transversal e meridional, os quais guardam características geológicas gerais bem particularizadas. O segmento central da província está balizado por dois expressivos lineamentos (Patos ao norte e Pernambuco, ao sul), que são zonas de cisalhamento subparalelas de direção geral E-W, que dão forma retangular a esta zona central. Estes lineamentos estão afastados entre si em média de $150 \mathrm{~km}$, e podem ser seguidas da faixa costeira até a Província Parnaíba, no Nordeste Ocidental, com diversas feições estruturais e morfológicas associadas ao longo destes marcantes tratos retilíneos.

Provavelmente este conjunto de cinturões de cisalhamento emparelhados teve extensão para o continente africano (Garoua-Patos, Pernambuco-Adamauoa), em tempos e montagem pré-cretácicos, conforme já proposto por Trompette (1994), que chamou esta feição transcontinental de median shear corridor.

O domínio setentrional da província, ao norte do lineamento de Patos, é caracterizado pelas freqüentes exposições de terrenos de alto grau da colagem paleoproterozóica (algumas poucas rochas supracrustais desta idade), e algumas esparsas de faixas supracrustais neoproterozóicas, de caráter residual (vestigial belts).

O domínio meridional, ao sul do lineamento de Pernambuco é o que circunscreve a periferia norte do Cráton do São Francisco, contendo faixas supracrustais neoproterozóicas marginais (pelítico-carbonáticas) e distais (vulcano-sedimentares) importantes e, nestas, a presença de basement inliers de tipos bastante diversos (vide Brito Neves et al., 2000), penetrados por notável contingente de rochas graníticas brasilianas, no chamado Maciço Pernambuco - Alagoas.
No interior da Zona Transversal - ZT (Figuras 1 e 2), e de forma diagonal a este domínio central interlineamentos, destaca-se uma zona elevada, palmilhada de granitos e sienitos neoproterozóicos, que tem traçado sigmoidal, e que se acopla em suas terminações, respectivamente ao lineamento Patos (para o norte, na extremidade leste) e ao lineamento de Pernambuco (para o sul, na extremidade oeste). Esta feição geológica e morfológica aqui discutida - a Zona Tectônica Teixeira-Terra Nova, ZTTTN - subdivide a Zona Transversal em dois contextos diferentes, ocupados por terrenos tectono-estratigráficos distintos, consoante observação de vários autores, inclusive com suporte adicional de dados geofísicos (vide Santos et al., 1997), e dos dados isotópicos que serão aqui realçados. No mapa aeromagnético (campo total sem IGRF) produzido pela CPRM - Serviço Geológico do Brasil (inédito), esta zona linear está relativamente bem marcada consoante um trende determinado de anomalias negativas, alinhamento este suficientemente destacado daqueles das faixas móveis e outros terrenos que lhe são adjacentes.

Antes de se constatar a importância desta segmentação da província acima postulada, Brito Neves (1975) havia reconhecido a peculiaridade desta zona linear, cunhando a designação de "Zona Geanticlinal de Teixeira", compreensível para a linguagem fixista da época. Igualmente, Sial (1986), impressionado com plutonismo sienítico desta zona (principalmente no ramo sul da zona linear) discriminoua com a denominação de "Syenitoid Line".

Para o norte e noroeste desta zona ficam os terrenos de baixo grau metamórficos do Riacho Gravatá - RG (vulcanosedimentar, Eoneoproterozóico) e Piancó-Alto Brígida-PAB (Neoproterozóico, também chamados de Santana dos Garrotes, consoante Bittar, 1998).

Para o sul e sudeste estão situados os terrenos de médio a alto grau metamórficos do Alto Pajeú - TAP (metagrauvacas com diversas intercalações de rochas vulcânicas e ortognaisses diversos de natureza granítica e granodiorítica, ditos "Cariris Velhos") e do seu embasamento paleoproterozóico (Terreno Alto Moxotó - TAM, ortognaisses diversos com intercalações anfibolíticas, cálcio-silicatadas, 
xistosas e até máfico-ultramáficas, de história policíclica). Estes terrenos da porção ao sul do ZTTTN se estendem do extremo leste da Paraíba ao sudoeste de Pernambuco, e que têm sido objeto de vários trabalhos recentes sobre a província em epígrafe (vide mapas geológicos estaduais recentes de Pernambuco, 2001 e da Paraíba, 2002, editados pela CPRM, entre outros).

No presente trabalho, os autores procurarão abordar a ZTTTN, pelo seu comportamento geológico geral (no Proterozóico e Fanerozóico), com ênfase nos dados isotópicos, tanto das rochas do seu embasamento como do cortejo de plutões graníticos e sieníticos nelas intrudidas. No caso do embasamento, isto será feito a partir de determinações diretas do mesmo, que apresenta exposições generalizadas de rochas eoneoproterozóicas (Ciclo Cariris Velhos, ortognaisses do TAP), e mais localmente, nas poucas exposições conhecidas de unidades mais antigas, paleoproterozóicas.

$\mathrm{O}$ atrativo especial desta zona linear sigmoidal, que marcadamente se situa longitudinal à linha que separa terrenos eoneoproterozóicos (limite preferencial entre o TAP e o RG), é a exuberância do porte de granitos e sienitos brasilianos/neoproterozóicos, de diversas tipologias e dimensões. E porque os registros isotópicos $\mathrm{Sm} / \mathrm{Nd}$ destas intrusivas, de forma inusitada, apontam para protólitos com valores de idade modelo $\left(\mathrm{T}_{\mathrm{DM}} \sim 2,1 \mathrm{Ga}\right)$ da parte média do Paleoproterozóico (período Riaciano), ou seja, a participação/ contaminação efetiva por componentes do embasamento. Nestes termos e nesta oportunidade é válido e justo adiantar que, praticamente quase todos os tipos graníticos mais típicos da Província Borborema, descritos nas sínteses de Ferreira et al. $(1998,2004)$ assim como quase todas as supersuítes plutônicas propostas por Santos e Medeiros (1999), se fazem representar ao longo do "alto" tectônico em epígrafe (vide síntese descritiva do Quadro 1).

A presença de rochas, estruturas e blocos do Paleoproterozóico (com alguns seed nuclei arqueanos), retrabalhados diversamente, compondo os mais diferentes tipos de basement inliers, tem sido exaustivamente enfocada por muitos autores (vide Brito Neves et al., 2000; entre outros) como característica da trama da colagem do embasamento da Borborema. Mas, da forma como aqui será discutido, a ZTTTN será considerada como elemento tectônico distinto, estrelando nova e interessante forma de participação do embasamento retrabalhado na trama do branching systems of orogens que caracteriza a esta província estrutural, porção de Gondwana Ocidental. Ou seja, a identificação de tratos do embasamento (crustais e litosféricos) será feita muito mais pela forma indireta, pelas informações inferidas nos plutões nele intrusivos do que por exposições francas. Até o presente, este tipo singular de manifestação da litosfera paleoproterozóica do embasamento não tem análogos conhecidos na Plataforma Sul Americana, ou similares em todos os descendentes de Gondwana. Como também já mencionado, esta zona - especial nos termos geológicos e geotectônicos acima preliminarmente expostos - apresenta também significativo e distinto registro linear nos levantamentos aerogeofísicos regionais.

No Fanerozóico, especialmente no Cenozóico (desde Paleogeno?), esta zona linear mostrou comportamento diferenciado, tendo sido um dos eixos principais de exaltação epirogenética da província (Csjaka, 1958), devido ao que foi aproveitada em grande parte de sua extensão (cotas elevadas acima de 800 m são muito comuns) para o traçado dos limites entre os estados da Paraíba e Pernambuco. Ao longo desta linha soerguida, de muitos divisores de água, de clima mais ameno (na verdade, um microclima) se localiza o Pico do Jabre, ponto culminante do Nordeste, com cota de aproximadamente $1.197 \mathrm{~m}$, entre as cidades de Maturéia e Mãe D’Água, situado de forma muito interessante (e demandando estudos neotectônicos) como alto topográfico entre duas frações de planalto (para leste e para oeste) encimadas por depósitos terciários (planaltos de cotas no entorno de $800 \mathrm{~m})$.

\section{EMBASAMENTO PALEOPROTEROZÓICO AFLORANTE DA ZTTTN}

As rochas do embasamento paleoproterozóico afloram ao longo da ZTTTN apenas a noroeste de Serra Talhada (ali designadas informalmente de "Complexo Serra Talhada", por Bittar, 1998), entre as localidades de Serra Talhada, Luanda e Bernardo Vieira, em Pernambuco. Outras exposições esporádicas são apontadas nas imediações de Manaira (Bittar, 1998) e imediações de Pocinhos - PB, na extremidade oriental do ZTTTN (Archanjo e Fetter, 2004), ambas carecendo de estudos mais detalhados.

Ao norte e noroeste de Serra Talhada, predominam ortognaisses de granulação média, textura granoblástica a milonítica, com composição geral variável de tonalítica a granítica, associadas com bandas discretas de anfibolito. $\mathrm{O}$ aspecto bandado predomina no campo, sendo comuns algumas invasões, penetrações discordantes e concordantes de migmatitos diatexíticos, além do seccionamento desta foliação principal por discretas zonas de cisalhamento $\left(\mathrm{S}_{\mathrm{n}+2}, \mathrm{NE}-\mathrm{SW}\right.$, vide Campos Neto et al., 1994). Diques diversos de rochas granodioríticas, sieníticas e outros (associados aos plutões regionais) aparecem também recortando estes ortognaisses.

Em Serra Talhada e imediações noroeste ocorre uma pequena faixa de rochas xistosas a muscovita e biotita, de natureza metagrauváquica, que foram cartografadas por Bittar (1998) e aludidos como pertencentes ao Complexo Sertânia (unidade que na verdade foi definida e ocorre bem 


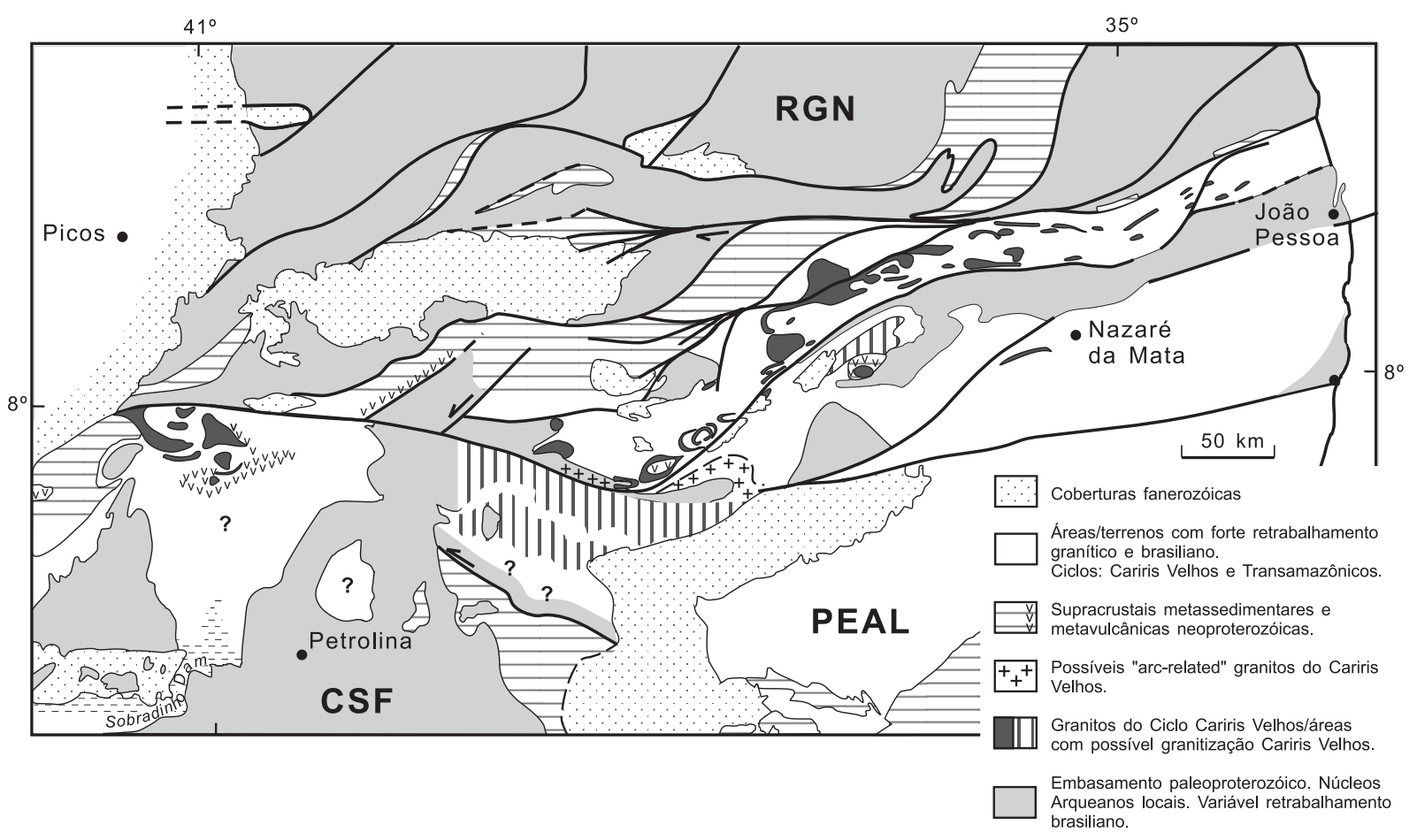

Figura 1. Mapa esquemático da parte central e meridional da Província Borborema, enfatizando os domínios do embasamento da colagem paleoproterozóica, as faixas móveis/terrenos eoneoproterozóicos (Cariris Velhos) e as faixas de supracrustais do Neoproterozóico Superior. Os lineamentos Patos, ao norte, e Pernambuco, ao sul, delimitam a chamada Zona Transversal (Brito Neves et al., 2000).

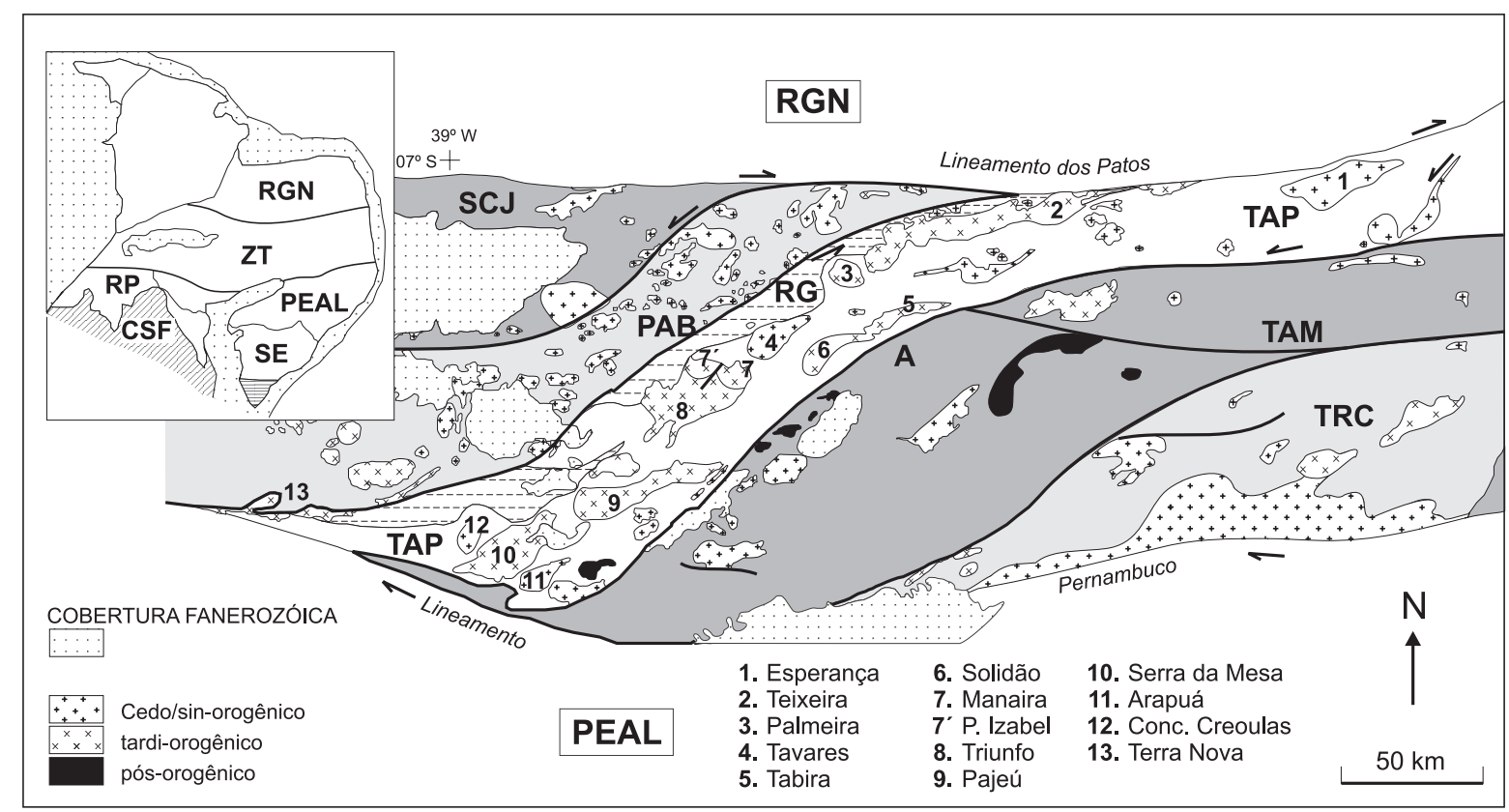

Figura 2. Terrenos da Zona Transversal e adjacências: RGN - Rio Grande do Norte, SJC - São José do Caiano, PAB - Piancó-Alto Brígida, RG - Riacho Gravatá, TAP - Alto Pajeú, TAM - Alto Moxotó, RC - Rio Capibaribe. Os corpos graníticos alinhados segundo a ZTTTN são de NNW para ESW: 1. Esperança-Pocinhos, 2. Teixeira, 3. Palmeira, 4. Tavares, 5. Tabira, 6. Solidão, 7. Manaira, 7’. Princesa Izabel, 8. Triunfo, 9. Pajeú, 10. Serra do Man, 11. Arapuá, 12. Conceição das Creoulas, 13. Terra Nova. Para detalhes, vide Santos e Medeiros (1999) e Ferreira et al. (2004). 
mais ao sul - ao sul do Terreno Alto Moxotó -, Santos et al., 2003), onde está sua localidade típica. Nas imediações oeste, norte e leste de Pocinhos, ao norte do plúton topônimo e servindo como encaixantes do mesmo, foram identificados esparsos afloramentos de ortognaisses profundamente laminados (afetados pelo Lineamento Patos, ao sul deste), que parecem partícipes deste embasamento paleoproterozóico.

Alguns dados isotópicos para estas rochas de alto grau têm indicado idades modelo ( $\mathrm{Sm}-\mathrm{Nd}$ ) paleoproterozóicas e/ ou mais antigas (vide discussão à frente). Estas rochas são aqui relacionadas e consideradas como as únicas exposições diretas conhecidas, até o presente, de embasamento paleoproterozóico na ZTTTN, ao longo do seu dorso principal.

O Terreno Alto Moxotó - TAM ocorre ao sul do Terreno Alto Pajeú - TAP, da área de Floresta do Navio, Pernambuco, até imediações de João Pessoa, Paraíba, onde está embasando a Faixa Sedimentar Costeira (ao sul da Praia de Lucena). De certa forma, este terreno de rochas paleoproterozóicas (ortognaisses principalmente) se distribui em grande parte paralelo ao sul da ZTTTN, delimitando (e cavalgando) ao sul o Terreno Alto Pajeú, consoante integração da cartografia geológica feita por Santos et al. (2002), Mapa Geológico do Estado da Paraíba, onde o TAM foi considerado como parte de uma grande massa alóctone (ali chamada de "nappe de Jabitacá").

Para os domínios imediatamente ao norte da ZTTTN (como sejam, Riacho Gravatá - RG e Piancó-Alto Brígida PAB), não há indicações diretas de presença do embasamento. Mas, devem ser mencionados registros bastante pontuais de raros dados $\mathrm{T}_{\mathrm{DM}}$ para supracrustais superiores a 1, $8 \mathrm{Ga}$ (vide tabelas e gráficos, mais à frente).

Ao norte-noroeste destes terrenos RG e PAB, após a larga zona de cisalhamento sinistral de Boqueirão dos Coxos (hoje chamada de Igaraci), aparece uma fração do embasamento paleoproterozóico, nas imediações de São José do Caiano. Trata-se provavelmente de uma porção secionada do Terreno Rio Grande do Norte - RGN (Brito Neves et al., 2000; Santos et al., 1997), outrora atuante como parte de uma massa continental imponente (antes e durante o Ciclo Brasiliano), transformada em terreno no arcabouço final do Ciclo Brasiliano.

\section{TERRENOS SITUADOS AO NORTE DA ZTTTN}

\section{Complexo/Terreno Riacho Gravatá (RG)}

O Complexo Riacho Gravatá (Campos Neto et al., 1994; Bittar, 1998) foi a designação aplicada para a faixa de rochas supracrustais situadas entre a ZTTTN e a Zona de
Cisalhamento da Serra do Caboclo, e sua continuação/ ramificação para sudoeste, a Zona de Cisalhamento Fernandes Vieira, numa faixa de direção geral WSW-ENE. Esta unidade/terreno (corretamente desmembrada da designação original de faixa Piancó-Alto Brígida) é composta de uma sucessão de metapsamitos (quartzitos inclusive) e metapelitos diversos, incluindo termos turbidíticos, com diversificada e freqüente contribuição de rochas metavulcânicas, ácidas, intermediárias e básicas (ocasionalmente rochas ultramáficas e tufos máficos), com rochas cálcio-silicáticas e carbonáticas ocorrendo subordinadamente. Cerca de cinco unidades (de A a E) litodêmicas foram descritas e cartografadas por Bittar (1998) na área de sua tese, o que é o mais completo acervo de dados para esta unidade.

Todo o conjunto é extremamente cisalhado, sendo conspícua a foliação gerada por cisalhamento dúctil $\left(\mathrm{S}_{\mathrm{n}+1}\right.$, Bittar, 1998) mas com certa freqüência estruturas primárias (acamadamento, estruturas de corte-e-preenchimento, contatos etc.) podem ser observadas. O metamorfismo regional predominante é nas facies epidotoanfibolito a anfibolito, com retrogressão local ao facies dos xistos verdes (Bittar, op. ct.), com regimes de pressões relativamente elevadas ( 7 a 9 kbar).

As condições tanto da tectônica formadora (rifte de manto ativado evoluindo para bacia oceânica??) como da tectônica deformadora (ambiente de subducção?, consoante Bittar, op. ct.), e as relações tempo-espaço com as unidades assemelhadas do TAP mais ao norte (Complexo São Caetano do Navio, de grau metamórfico na facies anfibolito) são ainda desconhecidas de fato. Trata-se de um terreno, onde o registro vulcano-sedimentar é incompleto, pois é fração apenas de um desenvolvimento mais amplo, delimitado entre zonas de falhas. A idade do processo vulcano-sedimentar é da ordem de $975 \mathrm{Ma}$ (Brito Neves et al., 1995; Kozuch, 2003), pouco mais antigo que as demais rochas vulcânicas e plutônicas do Ciclo Cariris Velhos (ca. 960 Ma) do TAP, embora em ambos os casos imprescindam de refinamento de dados.

\section{Terreno Piancó-Alto Brígida (PAB) - Grupo "Cachoeirinha"/Unidade Santana dos Garrotes}

Este terreno (Complexo Cachoeirinha, de Bittar, 1998) de desenvolvimento neoproterozóico ocorre ao norte da Zona de Cisalhamento de Serra do Caboclo, compreendendo um amplo sistema deposicional turbidítico metamorfizado na facies xisto verde, composto por duas unidades silícicoclásticas principais.

A Formação Serra de Olho d'Água (Bittar, 1998), de posição basal e descontínua longitudinalmente, é composta 
por conglomerados polimícticos, de matriz arenosa e areias argilosas, com clastos até decimétricos, com espessura aparente próxima dos $1.000 \mathrm{~m}$, sendo a provável facies proximal de contexto turbidítico mais amplo.

A Formação Santana dos Garrotes (Bittar, 1998), no topo, dominante em extensão e magnitude, é caracterizada por pacotes turbidíticos areno-argilosos (com alguns metagrauvacas e metassedimentos químicos ferríferos) de baixo grau de metamorfismo, com esparsas intercalações de rochas metavulcânicas básicas, intermediárias e ácidas, provavelmente de ambiente marinho. Alguns valores recentes e inéditos (W. R. Van Schmus, inédito) de zircões detríticos apontam para o contexto geral de idade do Neoproterozóico Superior (zircões ca. $640 \mathrm{Ma}$ ), o que é plenamente ratificado na análise do quadro de idades $T_{D M}$ (a ser discutido posteriormente).

Ao longo da "faixa Cachoeirinha" - designação informal muito utilizada no Nordeste - não há ocorrências conhecidas de terrenos do embasamento, nem paleoproterozóicas nem eoneoproterozóicas. Foram encontradas algumas indicações da presença esporádica de substrato antigo, auferido de idades $\mathrm{T}_{\mathrm{DM}}$ de supracrustais (e. g., amostras SPAB-Fi-75, $\mathrm{T}_{\mathrm{DM}}=2,8 \mathrm{Ga}$, filitos e Minador do Sal, $\mathrm{T}_{\mathrm{DM}}=1,85-1,92 \mathrm{Ga}$, meta-andesito).

As primeiras ocorrências concretas de rochas do embasamento estão ao norte deste terreno, a noroeste da zona de cisalhamento de Boqueirão dos Coxos/Igaraci (em São José do Caiano), como já mencionado, e ao norte do PAB, ou seja no contexto ao norte do Lineamento de Patos (no Terreno Rio Grande do Norte - RGN, domínio setentrional da Borborema), vide Brito Neves et al. (2000).

\section{TERRENOS SITUADOS AO SUL DA ZTTTN}

\section{Terreno Alto Pajeú (TAP)}

Na parte ao sul da ZTTTN, do meridiano de $39^{\circ} 00$ para a área costeira, ao norte de João Pessoa (entre Lucena e Mataraca), ocorre uma faixa de metamorfitos com cerca de $500 \mathrm{~km}$ de comprimento e ca. $40 \mathrm{~km}$ de largura, com orientação geral WSW-ENE. Esta faixa/terreno tectono-estratigráfico do Alto Pajeú é composto por uma seqüência vulcano-sedimentar a sedimentar, imatura (Complexo São Caetano), que é cortada e intercalada por dezenas de corpos tabulares e pequenos stocks de ortognaisses (tipos Ambó, Recanto, Rachinha etc. nas designações informais locais), bastante diversificados, mas com algumas feições lito-estruturais e composicionais (muscovita, biotita, granada, por vezes turmalina) muito características, sempre preservadas.

Em conjunto, estes gnaisses e as supracrustais encaixantes têm sido aludidos ao Ciclo Cariris Velhos, do início do Toniano, ca. 970 - 960 Ma, consoante Brito Neves et al. (1995; 2000) e Kozuch (2003). Provavelmente, este sistema orogênico teve todo o seu desenvolvimento, desde o complexo contexto de domínios paleogeográficos (bacias oceânicas pequenas?) até os principais eventos deformacionais (estilos contracionais muito importantes) no intervalo de tempo entre 990 - $930 \mathrm{Ma}$ (Kozuch, 2003). O alinhamento geral WSW-ENE, já mencionado, foi adquirido (ou fortemente influenciado) posteriormente com a sobreposição dos processos tardi-orogênicos das faixas móveis (e dos lineamentos) do Ciclo Brasiliano.

De fato, do Ediacarano ao início do Paleozóico (550 - $510 \mathrm{Ma}$ ), esta faixa foi submetida a importante overprint tectono-metamórfico do Brasiliano, auferindo sua forma atual consoante a evolução das faixas/terrenos Piancó-Alto Brígida - PAB e Rio Capibaribe - RC (Santos et al., 2002) e a estruturação final, pós-extrusão, da Província Borborema. São de destaque entre estes eventos, a ocorrência de processos de migmatização (localmente muito importantes) e a penetração por granitos (diversamente colocados em área), além dos intensos movimentos direcionais ligados à extrusão, tanto daqueles lineamentos maiores que definem a Zona Transversal como de muitos outros, do interior desta Zona (vide síntese de Brito Neves et al., 2000).

Em verdade, somente alguns poucos corpos graníticos brasilianos têm sido identificados no interior do TAP (ao sul do ZTTTN), o que o caracteriza e que é feição que o distingue dos demais terrenos. Por outro lado, e de forma conspícua, o TAP abriga, na sua porção mais ao norte, a série quase contínua de granitóides brasilianos que perfaz grande parte da ZTTTN, e o que é o grande chamariz desta unidade tectônica. Deve ser inclusive mencionado casos (batólitos de Tavares e Palmeira, pelo menos), onde as exposições dos ortognaisses do TAP podem ser observados aflorando francamente ao sul, mas também ao norte dos corpos intrusivos. De forma que a ZTTTN se localiza e se caracteriza como a fração da borda norte do TAP, perlongada por batólitos graníticos brasilianos (pouco ao sul do contato/limite do TAP com o RG).

O limite ao sul do TAP, para com rochas de seu embasamento paleoproterozóico - Terreno Alto Moxotó -, em grande parte é marcado por ramos de zonas de cisalhamento (Afogados de Ingazeira, Livramento/São João do Cariri etc.) e empurrões (a "nappe da Serra de Jabitacá" de Santos et al., 2002). Mas, é necessário acrescentar que (diferentemente do que fora preconizado anteriormente), tanto há ocorrências de frações do embasamento paleoproterozóico no interior do TAP, como há ocorrências de supracrustais e granitóides Cariris Velhos que extrapolam os limites normalmente traçados entre o TAP e o TAM em trabalhos pretéritos, faltando uma melhor discriminação cartográfica destes limites e destas ocorrências.

As assembléias de rochas supracrustais da principal 
unidade do TAP, o Complexo São Caetano do Navio, são constituídas de rochas bandadas, com biotita e muscovita (+ granada), xistos e metagrauvacas predominantes, com intercalações de metadacitos (alguns metabasaltos), metariolitos e alguns poucos metacarbonatos, sob facies anfibolito alto, com migmatizações freqüentes.

Os corpos gnáissicos (ditos "Cariris Velhos", Figura 1) são leucocráticos, de pequeno porte em geral, cortando e se intercalando nas rochas supracrustais do Complexo São Caetano, e apresentam composição variada de sienogranitos a granodioritos. Estas rochas são usualmente ricas em $\mathrm{SiO}_{2}, \mathrm{~K}_{2} \mathrm{O}$, com razões $\mathrm{Rb} / \mathrm{Sr}$ elevadas, tendo muscovita e biotita como minerais típicos (às vezes, granada, sillimanita e turmalina). A despeito da pequena porcentagem de xenólitos de xistos nos ortognaisses, os dados geoquímicos e outras inferências regionais apontam para origem em regimes colisionais para grande parte destes gnaisses (em parte, por fusão dos xistos).

Uma forte deformação tangencial é dominante neste conjunto de associações do TAP $\left(\mathrm{D}_{\mathrm{n}+1}\right)$, com indicadores cinemáticos para NW e NNW, sendo sobreposta por outra fase mais jovem de deformação, com dobras de planos axiais subverticais. Os processos tectônicos (sobretudo transcorrências) e magmatogênicos do Brasiliano são encontrados amplamente, e o aquecimento promovido por este ciclo (dados Ar/Ar inéditos, ca. 520 - $515 \mathrm{Ma}$ ) são generalizados, ocorrendo mesmo em porções distantes das falhas e granitos deste ciclo do Eoneoproterozóico. De forma que a preservação de idades $\mathrm{Rb}$-Sr do Eoneoproterozóico em muitas metavulcânicas e ortognaisses (Brito Neves et al., 1995) é de certa forma um fato a ser destacado e intrigante.

Até o presente, no território brasileiro (e africano, Toteu et al., 2002), não foram encontrados equivalentes dos terrenos TAP e RG, em termos de composição geral e idade. Mas, isto deve ser considerado devido ao quadro pobre ainda do conhecimento geológico e geocronológico. Tanto no norte como no sul da Zona Transversal há indicações a serem perquiridas - da presença de equivalentes do Cariris Velhos.

\section{Terreno Alto Moxotó (TAM)}

O TAM ocupa e bordeja toda porção ao sul do TAP, a partir das cidades paraibanas de Mari e Lucena, na faixa costeira, até o oeste de Pernambuco, guardando paralelismo com os alinhamentos do TAP (ao sul) e da ZTTTN (ao norte).

Fundamentalmente, o TAM é composto por rochas ortognáissicas de alto grau e uma banda de supracrustais aluminosas mais ao sul (designado como Complexo Sertânia), datados do Paleoproterozóico (Riaciano Superior), de acordo com Santos et al. (2003).
Trata-se de um contexto singular de embasamento paleoproterozóico (sliver?) dentro de desenvolvimentos orogênicos mais novos (do Cariris Velhos, primeiramente, e depois dentro do contexto do Brasiliano), com algumas características especiais. Este contexto foi descrito extensivamente por Brito Neves et al. (2001a, 2001b) e Santos et al. (2002), entre outros.

Como síntese, a título de complemento, podem ser apontadas algumas das características especiais:

a. a riqueza de tipos de ortognaisses, desde termos mais plagioclásicos até mesmo termos sienograníticos, de fácil identificação, não obstante o imprint metamórfico sobreposto;

b. a presença de rochas trondhjemíticas e gabroanortosíticas, do paralelo de Pilar, na Paraíba até o oeste de Pernambuco. Ocorrências da gabro-acamadados, gabros com Fe-Ti-V, oficalcitos etc. são indicadores de um ambiente pretérito de convergência de placas (muito provavelmente do Paleoproterozóico);

c. a presença de muitos eventos de migmatização e granitização (supostamente Brasilianas), mas com poucos plútons do Brasiliano de fato;

d. o retrabalhamento tectônico ("nappe de Jabitacá", enfatizada no Mapa Geológico da Paraíba, zonas de cisalhamento etc.) e termal (os dados K-Ar invariavelmente apontaram valores neopreoterozóicos) verificado no Brasiliano, inclusive com a presença de enxames de diques máficos da etapa final, de extrusão (Brito Neves et al., em impressão);

e. a presença (mais ao sul) das supracrustais aluminosas de facies anfibolito (a granada e sillimanita) do Complexo Sertânia, dissertado recentemente por Santos et al. (2004);

f. a constância dos valores de idade $\mathrm{Rb}-\mathrm{Sr}$ (surpreendentemente mantidos urbi-et-orbi), e U-Pb em zircão (Kozuch, 2003) indicando valores paleoproterozóicos, mais precisamente do Riaciano, apesar da imponente deformação brasiliana, dúctil e cisalhante;

g. o comportamento também muito harmônico dos dados $\mathrm{Sm}-\mathrm{Nd}$, a ser posteriormente discutido, neste texto.

\section{AS ROCHAS GRANÍTICAS DA ZTTTN}

Desde o sul de Juazeirinho - PB (situado pouco ao sul do Lineamento de Patos, paralelo $7^{\circ} 15^{\prime}$ ) até o sul de Terra Nova - PE (imediações ao norte do lineamento de Pernambuco, paralelo $8^{\circ} 18^{\prime}$ ), perfazendo traçado diagonal à Zona Transversal (domínio retangular central da Borborema), se alinha um cortejo de plutões brasilianos, francamente intrusivos, incluindo praticamente todos os tipos já dissertados nas sínteses de tipos Ferreira et al. (1998, 2004), e de supersuítes de Santos e Medeiros (1999). 
Quadro 1. As principais rochas graníticas e sieníticas ao longo do ZTTTN. Sinopse descritiva.

\begin{tabular}{|c|c|c|c|}
\hline $\begin{array}{l}\text { Corpo / Dimensões } \\
\text { Forma / Idade }\end{array}$ & Composição / Afinidade & Feições Destacáveis & Referências Principais \\
\hline $\begin{array}{l}\text { TEIXEIRA } \\
800 \mathrm{~km}^{2}, \text { alongado, } \\
\text { E-W. } \\
\text { Idade }=\approx 620 \mathrm{Ma}\end{array}$ & $\begin{array}{l}\text { Anfibólio-granito a quartzo-monzonito. } \\
\text { Metaluminoso a peraluminoso (tipo I). }\end{array}$ & $\begin{array}{l}\text { Tendência shoshonítica } \\
\text { (KO = 5\%) } \\
\text { Muitos zircões detríticos. }\end{array}$ & Medeiros et al., 1995 \\
\hline $\begin{array}{l}\text { PALMEIRA } \\
120 \mathrm{~km}^{2}, \text { subelíptico, } \\
\text { NNW-SSE. } \\
\text { Idade =? }\end{array}$ & $\begin{array}{l}\text { Leucogranodiorito médio a biotita. } \\
\text { Metaluminoso a peraluminoso (tipo I). }\end{array}$ & Tendência trondhjemítica. & Medeiros et al., 1995 \\
\hline $\begin{array}{l}\text { TAVARES } \\
175 \mathrm{~km}^{2}, \text { periforme, } \\
\text { ENE-WSW. } \\
\text { Idade }=651 \pm 15 \mathrm{Ma}\end{array}$ & $\begin{array}{l}\text { Sienogranitos, quartzo-sienitos, } \\
\text { monzogranitos e quartzo-monzonitos. } \\
\text { Metaluminoso a peraluminoso. }\end{array}$ & $\begin{array}{l}\text { Cálcio-alcalino de alto } \\
\text { potássio. Excepcional } \\
\text { presença de estruturas } \\
\text { magmáticas primárias. }\end{array}$ & $\begin{array}{l}\text { Pessoa, } 2001 \\
\text { Brito Neves et al., } 2003\end{array}$ \\
\hline $\begin{array}{l}\text { TABIRA } \\
320 \mathrm{~km}^{2}, \text { alongado, } \\
\text { ENE-WNW. } \\
\text { Idade }=612 \pm 9 \mathrm{Ma}\end{array}$ & $\begin{array}{l}\text { Biotita granodioritos a monzogranitos } \\
\text { predominantes. Localmente diorítico. }\end{array}$ & $\begin{array}{l}\text { Encraves microgranulares } \\
\text { e/ou diques máficos sin- } \\
\text { plutônicos. }\end{array}$ & Araújo et al., 1997 \\
\hline $\begin{array}{l}\text { SOLIDÃO } \\
250 \mathrm{~km}^{2}, \text { forma en cornue, sul } \\
\text { de Tavares. } \\
\text { Idade }=574 \pm 54 \mathrm{Ma}\end{array}$ & $\begin{array}{l}\text { Monzogranitos dominantes e } \\
\text { granodioritos, a biotita, e hornblenda e } \\
\text { piroxênio. Tendência alcalina } \\
\text { metaluminosa. Afinidades } \\
\text { shoshoníticas. }\end{array}$ & $\begin{array}{l}\text { Granitóide cálcio-alcalino } \\
\text { fortemente fracionado. } \\
\text { "Clots máficos" orientados } \\
\text { pelo cisalhamento. }\end{array}$ & $\begin{array}{l}\text { Araújo et al., } 1996 \\
\text { Kozuch, } 2003\end{array}$ \\
\hline $\begin{array}{l}\text { PRINCESA IZABEL-MANAIRA } \\
150 \mathrm{~km}^{2} . \\
\text { Idade }=?\end{array}$ & $\begin{array}{l}\text { Granitos porfiríticos. Metaluminosos a } \\
\text { peraluminosos (tipo Itaporanga). }\end{array}$ & $\begin{array}{l}\text { Cálcio-alcalino de alto } \\
\text { potássio. Presença de } \\
\text { enclaves/autólitos básicos. }\end{array}$ & Kozuch, 2003 \\
\hline $\begin{array}{l}\text { TRIUNFO } \\
-500 \mathrm{~km}^{2}, \text { periforme cisalhado, } \\
\text { SW-NE. } \\
\text { Idade }=\sim 580 \mathrm{Ma}\end{array}$ & $\begin{array}{l}\text { Álcali-feldspato sienito com aegirina- } \\
\text { augita, granulação média (clássico } \\
\left.\text { batólito peralcalino, até } 13 \% \mathrm{~K}_{2} 0\right) \text {. }\end{array}$ & $\begin{array}{l}\text { Estruturas magmáticas } \\
\text { planares e lineares } \\
\text { presentes, inclusões } \\
\text { gabróicas e iroxeníticas. } \\
\end{array}$ & Ferreira, 1991 \\
\hline $\begin{array}{l}\text { PAJEÚ } \\
\text { } 300 \mathrm{~km}^{2} \text {, elipsoidal alongado, } \\
\text { periforme, } \\
\text { ENE-WSW. } \\
\text { Idade = ?? }\end{array}$ & $\begin{array}{l}\text { Sienito porfirítico com fenocristais de } \\
\text { feldspato potássico (até } 8 \mathrm{~cm}) \text {, sienitos } \\
\text { de granulação fina, enclaves } \\
\text { melanocráticos sieníticos e diques sin- } \\
\text { plutônicos. Cálcio-alcalinas de alto } \\
\text { potássio, metaluminosos a levemente } \\
\text { peraluminosos. }\end{array}$ & $\begin{array}{l}\text { Os dados químicos apontam } \\
\text { para ambientes orogênicos } \\
\text { pós-colisionais, a filiação é } \\
\text { shoshonítica a } \\
\text { ultrapotássica. }\end{array}$ & Encinas, 1996 \\
\hline $\begin{array}{l}\text { CONCEICCÃO CREOULAS } \\
>120 \mathrm{~km}^{2}, \text { subelíptico, } \\
\text { NNE-SSW. } \\
\text { Idade }=\sim 638 \pm 29 \mathrm{Ma}\end{array}$ & $\begin{array}{l}\text { Biotita-granodiorito porfirítico a } \\
\text { monzogranito, com epidoto } \\
\text { magmático. Intrusão diapírica forçada. }\end{array}$ & $\begin{array}{l}\text { Parte central e sul infestada } \\
\text { de enclaves quartzo- } \\
\text { dioríticos. }\end{array}$ & Basilino et al., 1999 \\
\hline $\begin{array}{l}\text { SERRA DO MAN } \\
>180 \mathrm{~km}^{2}, \text { subelíptico, irregular, } \\
\text { NE-SW. } \\
\text { Idade }=\sim 580 \mathrm{Ma}\end{array}$ & $\begin{array}{l}\text { Álcali-feldspato sienito, fino a médio, } \\
\text { com fenocristais de feldspato e } \\
\text { clinopiroxênio. Caráter ultrapotássico, } \\
\text { semelhante a Triunfo. }\end{array}$ & $\begin{array}{l}\text { Diques leucocráticos tardios } \\
\text { de composição sienítica. } \\
\text { Altos teores de Ba, baixos } \\
\text { teores de } \mathrm{Nb} \text {, Ta e Th. }\end{array}$ & Ferreira et al., 2002 \\
\hline $\begin{array}{l}\text { TERRA NOVA } \\
>150 \mathrm{~km}^{2} \text {, subelíptico alongado, } \\
\text { E-W. } \\
\text { Idade }=580 \mathrm{Ma} ?\end{array}$ & $\begin{array}{l}\text { Sienitos porfiríticos e quartzo-sienitos } \\
\text { cisalhados a hornblenda. Afinidades } \\
\text { shoshoníticas. }\end{array}$ & $\begin{array}{l}\text { Afetado pelo Lin. } \\
\text { Pernambuco, cortado pelo } \\
\text { Serra Livramento. } \\
\text { Anomalias de Ni de até } \\
500 \text { ppm. } \\
\end{array}$ & $\begin{array}{l}\text { Silva Filho e Guimarães, } 1991 \\
\text { Silva Filho et al., } 1993\end{array}$ \\
\hline $\begin{array}{l}\text { SERRA LIVRAMENTO } \\
\text { Filonar, alongado pelo Lin. } \\
\text { Pernambuco. }\end{array}$ & $\begin{array}{l}\text { Hornblenda sienitos, de variável } \\
\text { granulação, muito grosseira inclusive. } \\
\text { Intrusivo no Terra Nova. }\end{array}$ & $\begin{array}{l}\text { Alinhado pelo Lin. } \\
\text { Pernambuco, intrusivo no } \\
\text { Terra Nova. }\end{array}$ & Silva Filho e Guimarães, 1991 \\
\hline
\end{tabular}


Principalmente, estes corpos intrusivos brasilianos são dos grupos de idade 640 - 620 Ma e 580 - 570 Ma deste ciclo, consoante o quadro de idades proposto por Brito Neves et al. (2003). Algumas intrusivas fissurais mais jovens $\left(3^{\circ}\right.$ grupo de idades) também aparecem localmente, completando um quadro muito privilegiado de magmatismo de cedo a tardi-tectônico.

Praticamente, quase todos os plutões (e mesmo algumas das intrusivas fissurais) que ocorrem ao longo desta zona diagonal da Zona Transversal, pela sua relevância foram objeto de trabalhos já publicados, de fundo petrológico, petrográfico e geoquímico principalmente (alguns com paleomagnetismo e gravimetria inseridos). Muitos destes trabalhos (vide Quadro 1) estão escudados por dissertações de mestrados e teses de doutoramento, na maioria oriundas do Centro de Tecnologia e Geociências da Universidade Federal de Pernambuco, em grande parte via o NEG/LABISE (Núcleo de Estudos de Granitos - Laboratório de Isótopos Estáveis). De sorte, que apenas uma síntese descritiva dos principais corpos precisa constar de nosso texto, e os detalhes devem ser procurados nas muitas referências apresentadas.

Os tipos sieníticos caracterizam apenas o ramo mais ocidental desta zona, e deles foi evocada a designação de Sial et al. (1986) de syenitoid line, que não corresponde à expressão geológica regional de fato. Como visto no resumo apresentado (Quadro 1), a variedade petrográfica é considerável. Considerando o notável acervo bibliográfico preexistente - plenamente referenciada -, optamos pela alternativa de apresentar uma tabela esquemática e simplificada das principais feições interessantes ao nosso trabalho.

No tocante aos dados analíticos Sm-Nd, como já foi mencionado e será discutido, todos se apresentam de uma forma muito semelhante, com valores de $T_{D M}$ do Paleoproterozóico, indiciando um "substrato" ou fonte que conduz a esta ordem de idade, e a validade deste fato vem sendo repetidamente demonstrada nos últimos anos, para plutônicas e até mesmo intrusivas fissurais. Há exceções, como em Tavares, Princesa Izabel e Terra Nova, onde geralmente se verificam extraordinárias feições magmáticas primárias (vide Pessoa, 2003), com valores $\mathrm{T}_{\mathrm{DM}}$ bem mais baixos (ca. 1,3 Ga). Estas raríssimas exceções podem estar, indicando outra fonte/substrato, ou tão somente proporções de mistura (magma-embasamento) bastante próprias e diferente do cortejo regional, ou, finalmente, descontinuidade no substrato (reservatório) paleoproterozóico em proposição. Não há como tratar destes casos sem enveredar por especulações no presente momento da pesquisa, assim como não se pode deixar de os discriminar devidamente, para futuras investigações objetivas.

\section{DISCUSSÃO DOS DADOS ISOTÓPICOS DO EMBASAMENTO PALEOPROTEROZÓICO}

\author{
Área de embasamento de São José \\ de Caiano \\ (Tabela 1, Figura 3)
}

No segmento de embasamento ao norte-noroeste do terreno $\mathrm{PAB}$, o comportamento apresentado pelos dados isotópicos, apesar de em número pequeno, é altamente consistente, o que é reforçado quando é feita a comparação destes valores com aqueles de setores homólogos (substrato aflorante da ZTTTN, amostras do TAM).

Os dados de $\mathrm{T}_{\mathrm{DM}}$ apontam para valores do Paleoproterozóico (2,38 - 2,5 Ga, predominantemente) e o Arqueano (um único caso, 2,66 Ga), com tempos de residência crustal antigos em geral, consoante os valores do $\mathcal{E} \mathrm{Nd}$ negativos muito elevados para o tempo hoje.

Assumindo o tempo Paleoproterozóico (2000 Ma) como referência, verifica-se que praticamente todas as amostras analisadas apontam para valores de $\mathcal{E} \mathrm{Nd}$ fracamente negativos $(-2,5 \mathrm{a}-4,27)$. Estas rochas devem ter sido geradas no Paleoproterozóico (entre o Riaciano e o Orosiriano), com protólitos pouco mais antigos, sendo viável a presença de contribuição mantélica importante neste intervalo de tempo. Os resultados apresentados estão em harmonia com aqueles encontrados no Terreno Rio Grande do Norte, mais ao norte (Dantas, 1997), do qual este segmento crustal paleoproterozóico deve ter sido originado, e também com os valores a serem discutidos no TAM e no embasamento observado e inferido da ZTTTN.

A presunção de idade paleoproterozóica para este segmento, por várias razões (decorrentes do conhecimento geológico regional) é ratificada por um dado U-Pb em zircão preexistente, em ortognaisses de São José do Caiano ( $\mathrm{T}=2250 \pm 24 \mathrm{Ma}$, Kozuch, 2003).

\section{Área do embasamento aflorante da ZTTTN - norte/noroeste de Serra Talhada (Tabelas 2 e 3, Figuras 3 e 4)}

\section{Dados $\mathrm{Sm}-\mathrm{Nd}$, U-Pb e Rb-Sr}

No tocante aos resultados $\mathrm{Sm}-\mathrm{Nd}$, o comportamento isotópico dos ortognaisses desta área antiformal de exposição franca de rochas do embasamento da ZTTTN, serão repetidas todas as considerações esboçadas para aqueles da área do segmento de São José do Caiano.

Isto pode ser verificado na análise da Tabela 2 e na Figura 3, onde foram traçados os gráficos de evolução do $\mathrm{Nd}$ em conjunto com os dados de São José do Caiano. A identidade do comportamento isotópico é de tal ordem que 
dispensa comentários adicionais, o que aliado às observações/dados de campo confirmam que se tratam de contextos de mesma natureza e idade.

Na localidade de Jardim ( 7 km NW de Serra Talhada), há uma determinação apenas, U-Pb em zircão de Kozuch, 2003 $(\mathrm{T}=2136 \pm 14 \mathrm{Ma})$ de um ortognaisse que ratifica plenamente as considerações aqui colocadas.

Uma coleta de amostras dos ortognaisses foi feita para determinações $\mathrm{Rb}-\mathrm{Sr}$, tentando explorar ao máximo as variações das razões $\mathrm{Rb}$-Sr. Verifica-se moderada dispersão nos resultados obtidos (Tabela 3, Figura 4), principalmente para aquelas rochas mais ricas em $\mathrm{Rb}$. As feições de campo (deformação da foliação principal, indícios de migmatização etc., já dissertadas) podem explicar este comportamento.

Ainda assim, desprezando dois dos valores mais discrepantes, é possível visualizar um alinhamento isotópico (de referência) na ordem de $2100 \mathrm{Ma}$, fixando-se uma razão inicial de $\mathrm{Sr}^{87} / \mathrm{Sr}^{86}$ na ordem de 0,705 , certamente acarretando com isto valor muito elevado para o MSWD.

Considerado em conjunto com os dados Sm-Nd e U-Pb, este valor de idade $\mathrm{Rb}$-Sr ganha expressão e passa a ser um resultado significativo. Para explicar os valores acima e abaixo da linha de referência traçada há muitas possibilidades teóricas (retrabalhamento Brasiliano, por exemplo), mas não necessárias nesta oportunidade.

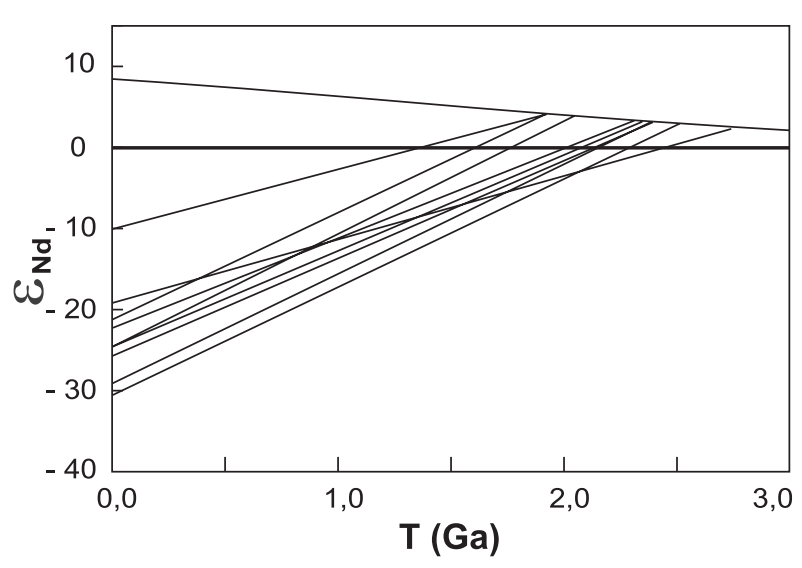

Figura 3. Diagrama de evolução isotópica do $\mathrm{Nd}$ para rochas do embasamento paleoproterozóico exposto na fração de São José do Caiano (fragmento do Terreno Rio Grande do Norte), na ZTTTN, ao norte-noroeste de Serra Talhada e nas imediações de Pocinhos. Comparar com a evolução do TAM, na Figura 6.

\section{Terreno Alto Moxotó/TAM (Tabela 4, Figura 5)}

Os dados obtidos em rochas do sliver do embasamento designado de TAM, nesta fração do seu desenvolvimento, são considerados muito homogêneos (vide Tabela 4, Figura 5) e consistentes. Estes dados são plenamente compatíveis com dados preexistentes da área mais a leste (do próprio TAM, Brito Neves et al., 2001b), e com aqueles valores do setor de São José do Caiano e do embasamento da ZTTTN, já discutidos.

Tanto na Tabela 4, como mais ainda no gráfico da Figura 5, o quadro geral é de um feixe de retas bastante homogêneo, mesmo para aquelas rochas de provável geração juvenil no Paleoproterozóico (retas mais à esquerda do diagrama).

Há um caso excepcional a ser comentado de início, pois foi de amostra repetida, (SPP-Mi-PT) indicando valor de $\mathrm{T}_{\mathrm{DM}}$ na faixa de 4,0 Ga. Falta detalhamento, como dados $\mathrm{U}-\mathrm{Pb}$ em zircão nesta amostra, mas é possível que se trate de porções do embasamento com influência de fontes arqueanas.

No geral, obtivemos valores $\mathrm{T}_{\mathrm{DM}}$ do Arqueano (4) e Paleoproterozóico ( 13 casos, acima de $70 \%$ dos casos), com $\varepsilon \mathrm{Nd}(0)$ fortemente negativos. $\mathrm{O} \mathcal{E N d}(\mathrm{t})$ considerado para o tempo $2000 \mathrm{Ma}$ indica certa variação de valores entre

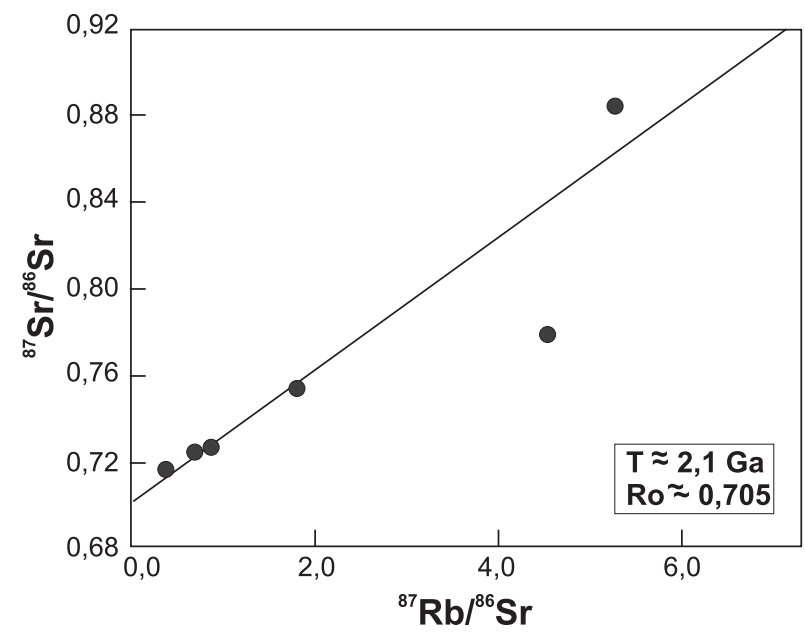

Figura 4. Diagrama $\mathrm{Rb}-\mathrm{Sr}$ traçado para os resultados analíticos dos ortognaisses e migmatitos da área a oeste de Serra Talhada (Santa Rita e adjacências), considerados como afloramentos da ZTTTN. Observa-se franca dispersão das rochas mais ricas em $\mathrm{Rb}$ (causada pelo retrabalhamento tectono-termal sobreposto), mas há alguns pontos analíticos ao longo da reta de $2100 \mathrm{Ma}$ (valor de idade obtido com o método $\mathrm{U}-\mathrm{Pb}$ em zircão). 
Tabela 1. Dados analíticos das determinações Sm/Nd no Bloco de São José do Caiano (provável segmento do Terreno Rio Grande do Norte).

\begin{tabular}{|c|c|c|c|c|c|c|c|c|c|c|c|}
\hline Lab. $\mathbf{N}^{\circ} / \mathrm{SPS}$ & Localidade & Rocha & Sm/ppm & $\mathrm{Nd} / \mathrm{ppm}$ & ${ }^{147} \mathrm{Sm} /{ }^{144} \mathrm{Nd}$ & ${ }^{143} \mathrm{Nd} /{ }^{144} \mathrm{Nd}$ & Erro & $\varepsilon N d(0)$ & $\varepsilon N d(t)$ & $\mathrm{T}_{\mathrm{DM} \text { (Ma) }}$ & Coordenadas \\
\hline 1974 & Spab-Mx-Npi & bio-gn. & 7,430 & 37,729 & 0,1191 & 0,511404 & 0,000010 & $-24,07$ & $-4,27$ & 2661 & $9208000 / 611200$ \\
\hline 1975 & Spab-Gn-Caj & ortogn. & 7,416 & 48,068 & 0,0933 & 0,511119 & 0,000010 & $-29,63$ & $-3,25$ & 2446 & $9197300 / 580000$ \\
\hline 1976 & Spab-Gn-SJC & migmat. & 6,877 & 42,899 & 0,0969 & 0,511141 & 0,000010 & $-29,20$ & $-3,75$ & 2495 & $9200000 / 576500$ \\
\hline Mk & $96-282$ & ortogn. & 6,314 & 43,840 & 0,0871 & 0,511062 & 0,000011 & $-30,74$ & $-2,60$ & 2380 & $9202000 / 570000$ \\
\hline
\end{tabular}

Tabela 2. Dados analíticos das determinações Sm/Nd dos ortognaisses do embasamento da ZTTTN - Trechos a oeste de Serra Talhada e a leste do Batólito de Teixeira.

\begin{tabular}{|c|c|c|c|c|c|c|c|c|c|c|c|}
\hline \multicolumn{12}{|c|}{ Trechos a oeste-noroeste de Serra Talhada e a leste do Batólito de Teixeira - PB } \\
\hline Lab. $N^{\circ} / S P S$ & Localidade & Rocha & Sm/ppm & $\mathrm{Nd} / \mathrm{ppm}$ & ${ }^{147} \mathrm{Sm} /{ }^{144} \mathrm{Nd}$ & ${ }^{143} \mathrm{Nd} /{ }^{144} \mathrm{Nd}$ & Erro & $\varepsilon N d(0)$ & $\varepsilon N d(t)$ & $\mathrm{T}_{\mathrm{DM}(\mathrm{Ma})}$ & Coordenadas \\
\hline $96-221$ & S Flores & ortogn. & 16,359 & 70,040 & 0,1412 & 0,511655 & 0,000010 & $-19,18$ & $-4,95$ & 2940 & $9128000 / 615000$ \\
\hline $96-227$ & Lag. Cruz & bi-gn. & 3,167 & 15,880 & 0,1206 & 0,511530 & 0,000009 & $-21,62$ & $-2,09$ & 2470 & $9147000 / 607500$ \\
\hline $96-271$ & Jardim & gnd-gn. & 7,958 & 48,110 & 0,1001 & 0,511314 & 0,000014 & $-25,82$ & $-0,99$ & 2310 & $9123000 / 569000$ \\
\hline $96-273$ & St. Rita & gnd-gn. & 7,526 & 39,360 & 0,1156 & 0,511503 & 0,000014 & $-22,14$ & $-1,32$ & 2390 & $9140500 / 563000$ \\
\hline SI-4-3220 & SI/St.Rita & ortogn. & 4,315 & 24,070 & 0,1084 & 0,511323 & 0,000010 & $-25,66$ & $-2,99$ & 2500 & $9126500 / 566500$ \\
\hline SI-5-3221 & SI/St. Rita & ortogn. & 4,117 & 24,560 & 0,1014 & 0,511147 & 0,000010 & $-29,08$ & $-4,63$ & 2590 & $9128000 / 566000$ \\
\hline 3078 ES 134 & W Pocinhos & gran.gn. & 6,598 & 43,898 & 0,0909 & 0,511382 & 0,000010 & $-24,50$ & 2,69 & 2064 & $9118500 / 820200$ \\
\hline 2607 Esfer & N Pocinhos & gran.gn. & 5,198 & 27,678 & 0,1136 & 0,511497 & 0,000049 & $-22,26$ & $-0,92$ & 2363 & $9216000 / 161000$ \\
\hline 2608 Esfer 2 & E Pocinhos & gran.gn. & 9,669 & 41,167 & 0,1420 & 0,512109 & 0,000009 & $-10,32$ & 3,72 & 1985 & $9217000 / 167000$ \\
\hline 3118-SCB PLT & Perim.260 & gn.gr. & 8,907 & 55,770 & 0,0966 & 0,511546 & 0,000011 & $-21,30$ & 4,43 & 1950 & $9201134 / 174688$ \\
\hline $94-116$ & Perim.260 & migm. & 8,560 & 53,230 & 0,0972 & 0,512295 & 0,000009 & $-26,20$ & 4,43 & 2280 & $9201134 / 174688$ \\
\hline 3118-SCBgnPLT & Perimetral & gn.gran. & 8,907 & 55,770 & 0,0966 & 0,511546 & 0,000011 & $-21,30$ & - & 1948 & $9201134 / 174688$ \\
\hline $94-116$ & Perimetral & migm. & 8,560 & 53,230 & 0,0972 & 0,512295 & 0,000009 & $-26,20$ & - & 2280 & $9201134 / 174688$ \\
\hline
\end{tabular}

Tabela 3. Dados analíticos das determinações Rb-Sr dos ortognaisses e migmatitos do embasamento da ZTTTN (ao nortenoroeste de Serra Talhada).

\begin{tabular}{|c|c|c|c|c|c|c|c|c|c|}
\hline Lab. $\mathbf{N}^{\circ} / \mathrm{SPS}$ & Localidade & Rocha & $\mathrm{Rb} / \mathrm{ppm}$ & Sr/ppm & $\mathrm{Rb}^{87} / \mathrm{Sr}^{86}$ & Erro/Rb & $\mathrm{Sr}^{87} / \mathrm{Sr}^{86}$ & Erro/Sr & Coordenadas \\
\hline 13726 & SIGnSTL2 & gn. & 115,7 & 404,9 & 0,828 & 0,023 & 0,72522 & 0,00007 & $9126000 / 567000$ \\
\hline 13727 & SIGnSTL3 & gn. & 80,7 & 356,7 & 0,656 & 0,019 & 0,72314 & 0,00008 & $9126500 / 566500$ \\
\hline 13728 & SIGnSTL4 & gn. & 58,0 & 433,5 & 0,388 & 0,011 & 0,71530 & 0,00009 & $9128000 / 566000$ \\
\hline 13729 & SIGnSTL5 & gn. & 92,1 & 151,0 & 1,773 & 0,050 & 0,75055 & 0,00009 & $9130500 / 565500$ \\
\hline 13730 & SIGnSTL6 & gn. & 111,7 & 71,7 & 4,540 & 0,127 & 0,77727 & 0,00007 & $9116000 / 565000$ \\
\hline 13731 & SIGnSTL7 & bio.gn. & 152,3 & 111,8 & 4,004 & 0,111 & 0,86471 & 0,00008 & $9116000 / 557500$ \\
\hline 13732 & SIGnSTL8 & gn.peg. & 184,4 & 102,6 & 5,291 & 0,147 & 0,88178 & 0,00009 & $9116000 / 557500$ \\
\hline
\end{tabular}


positivos ( 2 casos), fracamente negativos (entre 0 e -5 ), o que é a maioria, e apenas alguns casos ( 2 casos) apenas onde estes valores são fortemente negativos.

A interpretação preliminar, em coerência com dados U-Pb (Brito Neves et al., 2001) é a de um embasamento paleoproterozóico, com alguma herança arqueana local (terça parte dos casos amostrados), e com muitos casos (mais da metade das amostras processadas) que podem ser atribuídos à formação juvenil ou com pouca contaminação de crosta/ reservatório mais antiga.

Estes dados completam e traçam um quadro regional de desenvolvimento da região em apreço (Zona Transversal) entre dois domínios mais externos paleoproterozóicos por excelência: a noroeste o "São José do Caiano" (segmento deslocado do terreno RGN?) e ao sul e sudeste, o TAM. A ZTTTN seria, nestas circunstâncias, e diante dos dados apresentados e a serem discutidos, uma concentração quase linear, com escassas exposições, de unidades lito-estruturais paleoproterozóicas (de mesma natureza, semelhante ao TAM e do RGN/São José do Caiano), subdividindo diagonalmente o espaço tectônico entre os dois blocos paleoproterozóicos maiores.

Ao sul do TAM, na Zona Transversal se situa o Terreno Rio Capibaribe - RC, não discutido nesta oportunidade, onde voltam a ocorrer muitas supracrustais, que parecem ter sido (parte delas) de evolução neoproterozóicas, e onde as rochas do embasamento (consoante os primeiros resultados que dispomos) reiteram valores similares àqueles obtidos no TAM.

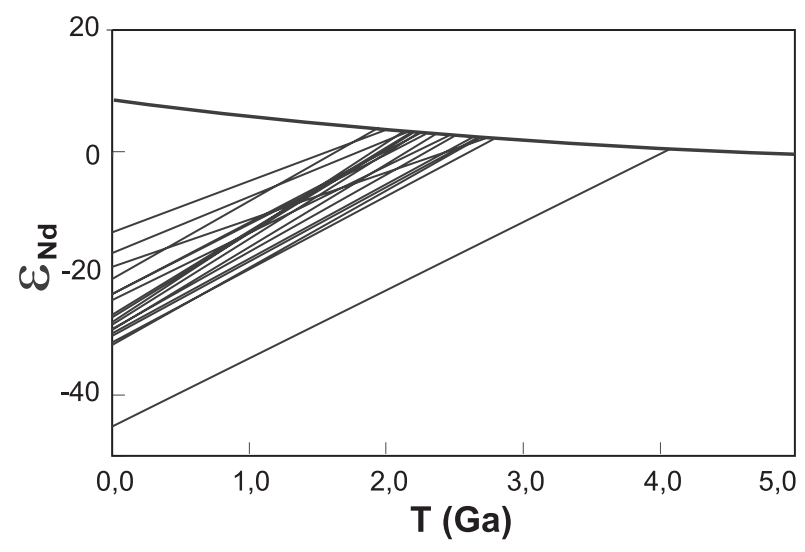

Figura 5. Diagrama de evolução isotópica do $\mathrm{Nd}$ para as rochas do embasamento do Terreno Alto Moxotó - TAM, na porção imediatamente sul e sudeste do TAP.

\section{DISCUSSÃO DOS DADOS ISOTÓPICOS DOS TERRENOS NEOPROTEROZÓICOS}

\author{
Rochas supracrustais de Santana dos \\ Garrotes, do PAB \\ (Tabela 5, Figura 6)
}

Na discussão dos dados do PAB, há três feições distintas a serem consideradas e discutidas. A primeira delas, considerada como sendo casos de excepcionalidade, tratamse de um filito (ardoseano, prateado, SPAB-Fi-75), intercalando metavulcânicas félsicas (SPAB-V-75), a noroeste de Manaira, e de um micaxisto granadífero (SPAM-Mx-Npi). Estes litotipos apresentam $T_{D M}$ do Arqueano $\left(\mathrm{T}_{\mathrm{DM}}=2,8 \mathrm{Ga} ; \mathrm{T}_{\mathrm{DM}}=2,66 \mathrm{Ga}\right)$ e valores elevados negativos de $\mathcal{E} \mathrm{Nd}$, tanto para o presente como para os tempos eoneoproterozóicos (Tabela 5, Figura $6, \boldsymbol{\varepsilon} \mathrm{Nd}=-33,9$ ). Estes dados são preliminarmente interpretados como representativos da influência/participação do embasamento paleoproterozóico, da porção marginal norte da faixa (onde ocorrem micaxistos) e de prováveis blocos mais antigos (microterrenos?) derivados do terreno RGN e compondo a trama do embasamento de PAB.

Há dois outros casos, de rocha vulcânica intermediária (latito de Minador do Sal) e de turbiditos (siliciclásticos da Barragem de Nova Olinda), de $\mathrm{T}_{\mathrm{DM}}$ paleoproterozóico $(1,8-1,9 \mathrm{Ga})$, com valores elevados negativos de $\varepsilon \mathrm{Nd}(-14 \mathrm{a}-24)$. Os turbiditos finos devem/podem ter suas fontes distantes (materiais d RGN, TAM) ou de

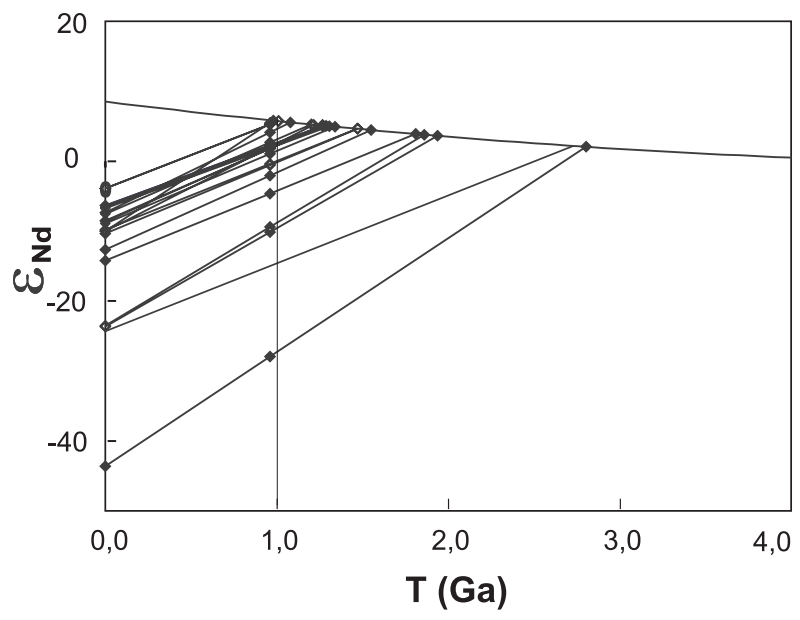

Figura 6. Diagrama de evolução isotópica do $\mathrm{Nd}$ para as rochas metassedimentares e metavulcânicas da Unidade Santana dos Garrotes ("Cachoeirinha" s. s., no terreno Piancó-Alto Brígida - PAB). 
Tabela 4. Dados analíticos das determinações Sm/Nd dos gnaisses do Terreno Alto Moxotó - TAM (ao sul e sudeste do TAP, na capa da "nappe da Serra de Jabitacá").

\begin{tabular}{|c|c|c|c|c|c|c|c|c|c|c|c|}
\hline Lab. N ${ }^{\circ} / \mathrm{SPS}$ & Localidade & Rocha & Sm/ppm & $\mathrm{Nd} / \mathrm{ppm}$ & ${ }^{147} \mathrm{Sm} /{ }^{144} \mathrm{Nd}$ & ${ }^{143} \mathrm{Nd} /{ }^{144} \mathrm{Nd}$ & Erro & $\varepsilon N d(0)$ & $\varepsilon N d(t)$ & $\mathrm{T}_{\mathrm{DM}(\mathrm{Ma})}$ & Coordenadas \\
\hline 1805-SPP Mi PTA & S Prata-PB & migm. & 15,625 & 86,827 & 0,1088 & 0,510321 & 0,000014 & $-45,20$ & $-22,78$ & 4070 & $7^{\circ} 47^{\prime}, 50 / 37^{\circ} 01^{\prime}, 00$ \\
\hline 1806-Sumé 2-gnd & N Sumé-PB & gnd & 23,054 & 1333,500 & 0,1044 & 0,511437 & 0,000010 & $-23,43$ & $-16,37$ & 2246 & $7^{\circ} 38^{\prime}, 10 / 36^{\circ} 53^{\prime}, 00$ \\
\hline 1809-SPP GRSB10 & W S. Branca & gnd & 12,622 & 88,613 & 0,0861 & 0,511180 & 0,000012 & $-29,65$ & $-21,19$ & 2307 & $7^{\circ} 31^{\prime}, 37 / 36^{\circ} 49^{\prime}, 36$ \\
\hline $96-201$ & Afogados & gn.gran. & 7,170 & 49,070 & 0,0883 & 0,511242 & 0,000015 & $-27,23$ & 0,60 & 2180 & $7^{\circ} 45^{\prime}, 18 / 37^{\circ} 37^{\prime}, 17$ \\
\hline $96-202$ & Afogados & bi-gnais. & 2,715 & 18,290 & 0,0898 & 0,511135 & 0,000012 & $-29,32$ & $-0,54$ & 2340 & $7^{\circ} 45^{\prime}, 18 / 37^{\circ} 37^{\prime}, 17$ \\
\hline $95-212$ & E Afogados & bi-gnais. & 4,167 & 25,040 & 0,1006 & 0,511108 & 0,000011 & $-29,84$ & $-5,20$ & 2610 & $7^{\circ} 46^{\prime}, 18 / 37^{\circ} 34^{\prime}, 01$ \\
\hline $1822-95-212 \# 2$ & E Afogados & bi-gnais. & 4,153 & 24,930 & 0,1007 & 0,511084 & 0,000013 & $-22,98$ & $-4,90$ & 2640 & $7^{\circ} 46^{\prime}, 18 / 37^{\circ} 34^{\prime}, 01$ \\
\hline $96-266$ & SW Afogados & encl.maf. & 12,172 & 82,710 & 0,0890 & 0,511265 & 0,000016 & $-26,79$ & 0,69 & 2160 & $7^{\circ} 47^{\prime}, 84 / 37^{\circ} 40^{\prime}, 95$ \\
\hline $96-264$ & SW Afogados & grey-gn. & 24,800 & 154,320 & 0,0972 & 0,511009 & 0,000012 & $-31,77$ & $-6,39$ & 2660 & $7^{\circ} 46^{\prime}, 32 / 37^{\circ} 39^{\prime}, 67$ \\
\hline $95-213$ & Igaraci-PE & grey-gn. & 3,792 & 23,770 & 0,0964 & 0,511566 & 0,000009 & $-20,91$ & 4,66 & 1910 & $7^{\circ} 50^{\prime}, 26 / 37^{\circ} 30^{\prime}, 76$ \\
\hline $96-254$ & SSW Igaraci & sien.gns. & 6,672 & 29,680 & 0,1377 & 0,511667 & 0,000009 & $-18,94$ & $-3,44$ & 2770 & $7^{\circ} 52^{\prime}, 50 / 37^{\circ} 32^{\prime}, 53$ \\
\hline $96-260$ & NE Sertania & sien.gns. & 10,525 & 51,290 & 0,1241 & 0,511782 & 0,000014 & $-16,69$ & 1,83 & 2130 & $7^{\circ} 57^{\prime}, 35 / 37^{\circ} 12^{\prime}, 76$ \\
\hline 96-225 & Faz. Exu & aug.gna. & 7,021 & 41,440 & 0,1024 & 0,511030 & 0,000015 & $-31,35$ & $-7,31$ & 2380 & $7^{\circ} 48^{\prime}, 35 / 37^{\circ} 22^{\prime}, 52$ \\
\hline 96-239/TAM & E Sit. Grossos & ton.gna. & 5,688 & 31,190 & 0,1102 & 0,511386 & 0,000017 & $-24,42$ & $-2,38$ & 2440 & $7^{\circ} 33^{\prime}, 59 / 37^{\circ} 14^{\prime}, 42$ \\
\hline 96-240/TAM & E Sit. Grossos & ton.gna. & 7,661 & 47,750 & 0,0970 & 0,511143 & 0,000015 & $-29,15$ & $-3,73$ & 2480 & $7^{\circ} 33^{\prime}, 05 / 37^{\circ} 13^{\prime}, 47$ \\
\hline 96-243/TAM & E O. Velho & mig.gr. & 12,718 & 72,220 & 0,1065 & 0,511438 & 0,000012 & $-23,41$ & $-0,39$ & 2270 & $7^{\circ} 38^{\prime}, 66 / 37^{\circ} 08^{\prime}, 01$ \\
\hline
\end{tabular}

Tabela 5. Dados analíticos das determinações $\mathrm{Sm} / \mathrm{Nd}$ na faixa/Terreno de Santana dos Garrotes ou Cachoeirinha s.s. (PAB).

\begin{tabular}{|c|c|c|c|c|c|c|c|c|c|c|c|}
\hline Lab. $N^{\circ} / S P S$ & Localidade & Rocha & Sm/ppm & $\mathrm{Nd} / \mathrm{ppm}$ & ${ }^{147} \mathrm{Sm} / /^{144} \mathrm{Nd}$ & ${ }^{143} \mathrm{Nd} /{ }^{144} \mathrm{Nd}$ & Erro & $\varepsilon N d(0)$ & $\varepsilon N d(t)$ & $\mathrm{T}_{\mathrm{DM} \text { (Ma) }}$ & Coordenadas \\
\hline 1974-Mx-Npi/(93-75) & $\mathrm{N}$ de Pianco & micaxisto & 7,430 & 37,729 & 0,11910 & 0,511404 & 0,000010 & $-24,07$ & $-4,27$ & 2661 & $9208000 / 611200$ \\
\hline SpabFi75 & 20 km NW Mana. & filito prata & 1,610 & 14,100 & 0,06915 & 0,510403 & 0,000009 & $-43,60$ & $-33,90$ & 2800 & $9160000 / 578600$ \\
\hline SPABxvSSG/(95-206) & S. Garrotes & filito & 11,969 & 65,048 & 0,11125 & 0,512194 & 0,000011 & $-8,38$ & $-1,83$ & 1240 & $9182500 / 612500$ \\
\hline SPAB V SSG/(95-207) & S. Garrotes & metadac. & 5,941 & 28,533 & 0,12590 & 0,512291 & 0,000014 & $-6,50$ & $-1,07$ & 1280 & $9182000 / 617500$ \\
\hline SPAB G SSG/(95-208) & S. Garrotes & folh.gran. & 4,420 & 27,159 & 0,09839 & 0,512125 & 0,000014 & $-10,02$ & $-2,48$ & 1215 & $9181000 / 611700$ \\
\hline SPABCpi1/(97-39) & C. Pires & metatufo & 2,310 & 12,090 & 0,11557 & 0,512181 & 0,000008 & $-8,92$ & $-2,71$ & 1333 & $9160000 / 578600$ \\
\hline SPABCpi2/(97-40) & C. Pires & metadac. & 5,970 & 31,960 & 0,11300 & 0,512250 & 0,000011 & $-7,57$ & $-1,15$ & 1200 & $9160000 / 578600$ \\
\hline SPABPi & 5 km E Piancó & gda.xisto & 5,840 & 28,130 & 0,12556 & 0,512299 & 0,000008 & $-6,60$ & $-1,20$ & 1280 & $9205600 / 622500$ \\
\hline $95-209$ & Nova Olinda & metasilt. & 9,316 & 47,640 & 0,11820 & 0,511909 & 0,000009 & $-14,21$ & $-8,21$ & 1800 & $9170000 / 605000$ \\
\hline $95-210$ & Nova Olinda & metarenito & 5,998 & 32,910 & 0,11050 & 0,511990 & 0,000010 & $-16,23$ & $-6,04$ & 1550 & $9170000 / 605000$ \\
\hline $96-286$ & Vz. Comprida & metariol. & 3,001 & 14,890 & 0,12190 & 0,512438 & 0,000015 & $-3,90$ & 1,84 & 1000 & $9194900 / 641300$ \\
\hline $96-285$ & Vz. Comprida & metabas. & 3,975 & 19,030 & 0,12630 & 0,512314 & 0,000016 & $-6,32$ & $-0,92$ & 1260 & $9194900 / 641300$ \\
\hline $97-201$ & Garra/SpabV RB & metagv. & 5,060 & 43,610 & 0,07010 & 0,512124 & 0,000014 & $-10,03$ & $-0,32$ & 980 & $9193400 / 644400$ \\
\hline $97-201 \# 2$ & Garra/SpabV RB & metagv. & 6,574 & 33,980 & 0,11700 & 0,512108 & 0,000016 & $-10,34$ & $-4,23$ & 1460 & $9193400 / 644400$ \\
\hline $97-202$ & B. Vista/SpabVBV & metafels. & 6,403 & 33,893 & 0,11420 & 0,512252 & 0,000012 & $-7,53$ & $-1,21$ & 1208 & $9209800 / 654800$ \\
\hline $97-203$ & B. vista/SpabVBV & metafels. & 1,784 & 9,020 & 0,11960 & 0,512135 & 0,000016 & $-9,82$ & $-3,91$ & 1460 & $9208500 / 655700$ \\
\hline $97-205$ & Fz. Jurema & vulcanocl. & 4,931 & 26,530 & 0,11240 & 0,512200 & 0,000014 & $-8,54$ & $-2,07$ & 1260 & $9204000 / 646100$ \\
\hline $97-206$ & Minador Sal & metalatito & 36,640 & 271,140 & 0,08170 & 0,511433 & 0,000009 & $-23,50$ & $-14,70$ & 1850 & $9204000 / 647000$ \\
\hline $97-206 \# 2$ & Minador Sal & metalatito & 8,329 & 58,430 & 0,08620 & 0,511424 & 0,000013 & $-23,69$ & $-15,23$ & 1920 & $9204000 / 647000$ \\
\hline $97-207$ & Aç. Conceição & metadacito & 4,615 & 27,060 & 0,10310 & 0,512262 & 0,000012 & $-7,33$ & $-0,15$ & 1080 & $9199000 / 647500$ \\
\hline
\end{tabular}


núcleos/blocos arqueanos menores do embasamento do PAB (atualmente não aflorantes). Para as metavulcânicas temos que pensar em fontes de contaminação e/ou eventos de fusão de rochas paleoproterozóicas e até mais antigas.

No entanto, para a maioria absoluta dos casos, há notável coerência de resultados, com $\mathrm{T}_{\mathrm{DM}}$ de valores mesoproterozóicos, sendo que em $80 \%$ dos casos valores são inferiores a $1500 \mathrm{Ma}$, e os valores de $\varepsilon \mathrm{Nd}_{(600)}$ (em $60 \%$ dos casos entre 0 e -3 ) fracamente negativos, com registro até mesmo de um (apenas um) dado positivo.

Por seu turno, valores de $\mathrm{T}_{\mathrm{DM}}$ acima de 1500 Ma são bem mais raros, como raros são os valores de $\mathcal{E} \mathrm{Nd}_{(600)}$ fortemente negativos (discutidos no parágrafo inicial deste item), cujas origens foram conjecturadas. O gráfico da Figura 6 destaca com relativa clareza em três conjuntos distintos de retas obtidas e de casos aqui relatados.

Nestes termos, pode-se admitir a preponderância de fontes juvenis (neoproterozóicas) e/ou de pequena residência crustal prévia, consorciada minoritariamente com fontes pré-neoproterozóicas na formação deste contexto sedimentar e vulcano-sedimentar do Neoproterozóico. A idade neoproterozóica da faixa sedimentar-vulcânica do PAB - Santana dos Garrotes - está suficientemente bem consignada, consoante dados U-Pb em zircão de Kozuch (2003), e por muitos outros dados ainda inéditos de SHRIMP (Van Schmus, inédito).

Estes valores fracamente negativos e o único valor positivo de $\mathcal{E} N d$ (localidade de Várzea Comprida, em metafelsito) são importantes destacar, como alerta a alguns autores que têm pugnado e propalado pela integridade e inviolabilidade do supercontinente Atlântica (da colagem paleoproterozóica) até os nossos dias. Uma crosta continental adelgaçada, com frações laterais oceânicas seria um quadro paleogeográfico hipoteticamente mais viável e consentâneo para acomodar as observações tanto da geologia regional como estes outros dados de natureza isotópica (vide modelo paleogeográfico esquematizado em cartoon na Figura 12).

Os dados do embasamento paleoproterozóico, ao norte (São José do Caiano) e ao sul do PAB (ZTTTN) e praticamente a ausência de indicadores de embasamento no interior de PAB são observações importantes a serem destacadas. Assim sendo, se este embasamento "siálico" paleoproterozóico ou mais antigo existiu, ele interferiu pouco na formação das rochas de Santana dos Garrotes, provavelmente era muito descontínuo e se achava bastante afinado por estiramento. De qualquer sorte, este embasamento teve um comportamento deveras diferente daquele ao longo do segmento de São José do Caiano (ao norte) e do cortejo de rochas plutônicas do ZTTTN (ao sul).

\section{Faixa/Terreno Riacho Gravatá - RG (Eoneoproterozóico) (Tabela 6, Figura 7)}

As rochas do terreno/faixa do Riacho Gravatá mostram um quadro muito característico e próprio quanto ao comportamento relativo aos isótopos $\mathrm{Sm}-\mathrm{Nd}$, comportamento este muito distinto das unidades geológicas que o confinam. Isto é válido para rochas metabásicas e metafélsicas, que foram aquelas mais insistentemente coletadas, e cujas determinações U-Pb em zircão (Van Schmus, 1995; Kozuch, 2003) são do Eoneoproterozóico, entre 950 - 975 Ma. Este valor de idade, da parte inferior do Neoproterozóico foi reiterado recentemente por determinações SHRIMP em zircões detríticos (dados inéditos de um dos co-autores, W. R. Van Schmus).

Temos que começar por exceções do conjunto, uma relativa a um tufo grafitoso (em Piaus) e outra relativa a uma rocha metabásica ao noroeste de Manaira, que são determinações que precisam ser refeitas. Estes dados são inconclusos e apontam contaminação por um "embasamento Arqueano", que pode ter existido alhures na condição de tratos microcontinentais, como já discutido em outros casos.

No tocante às demais rochas, a imensa maioria mostra valores de $\mathbf{T}_{\mathrm{DM}}$ entre 1,0 e 2,0 Ga, com concentração especial em valores entre 2,0 e $1,5 \mathrm{Ga}$ ( $81 \%$ dos dados). Ou seja, produtos de um reservatório/embasamento diferente daquele do PAB situado ao norte (após a Zona de Cisalhamento da Serra do Caboclo) e daquele do ZTTTN, situado mais ao sul, o que será ratificado na discussão dos valores de $\boldsymbol{E} \mathrm{Nd}$.

No tocante aos valores $\varepsilon \mathrm{Nd}_{(960)}$, há vários casos de valores positivos e de valores fracamente negativos, próximos a zero ( $70 \%$ dos casos). Os demais valores (30\%) são negativos, de forma moderada (entre $-3 \mathrm{e}-8$ ). Isto deixa bem claro e deve ser ressaltado sobre a importância de contribuição juvenil na formação das rochas do RG. Os casos de $\mathcal{E} \mathrm{Nd}$ das amostras de rochas metavulcânicas Juru $(\varepsilon \mathrm{Nd}=-0,26)$, os metagabros de Pau Ferro $(\mathcal{E} \mathrm{Nd}=3,76)$ e Alto Vermelho $(\boldsymbol{E} \mathrm{Nd}=0,81)$ podem ser pinçados como exemplos mais notórios das assertivas acima.

Estes valores, somados com aqueles de Santana dos Garrotes, são significativos para se postular um espaço tectônico amplo, sem embasamento "siálico paleoproterozóico" (se presente, esteve afinado por estiramento tectônico e fragmentado, descontínuo), e situado entre o embasamento da ZTTTN e do embasamento da fração de São José do Caiano. De certa maneira, o mesmo vai se poder dizer e concluir sobre o espaço tectônico entre a ZTTTN e o TAM, subjacente das rochas do TAP, a ser discutido mais à frente. 


\section{Metagrauvacas e ortognaisses do Terreno Alto Pajeú - TAP}

(Tabelas 7, 8 e 9, Figuras 8 e 9)

As metagrauvacas do Complexo São Caetano são consideradas pouco mais antigas (Brito Neves, 2001; Kozuch, 2003; ordem de duas dezenas de milhões de anos) do que os ortognaisses do Cariris Velhos, do que seriam as encaixantes. O comportamento isotópico destas unidades, ainda que parecidos, mostram algumas diferenças que devem ser ressaltadas (como nas Figuras 8 e 9).

No gráfico de evolução do $\mathrm{Nd}$ e nos dados isotópicos das metagrauvacas (parte final da Tabela 7) há uma exceção a ser primeiramente comentada, que é o caso do tufo vulcânico do oeste de São José do Egito de idade eoneoproterozóica, que apresentou idade $\mathrm{T}_{\mathrm{DM}}$ do Arqueano, sugerindo a possível influência ou fonte de algum núcleo Arqueano no embasamento remoto. Uma determinação $\mathrm{U}-\mathrm{Pb}$ SHRIMP em zircão mostrou grande variedade de procedência dos detritos ali presentes (de idades do Arqueano ao final do Mesoproterozóico, Kozuch, 2003).

Para as metagrauvacas, em $80 \%$ dos casos, os valores de $\mathrm{T}_{\mathrm{DM}}$ variam entre 1,5 e 2,5 Ga. Os valores de $\boldsymbol{\varepsilon} \mathbf{N d}$, em $\mathbf{5 0 \%}$ das vezes são positivos ( 2 casos) ou fracamente negativos, e nos demais casos (50\%) são moderadamente negativos (entre $-5 \mathrm{e}-17$ ). E nestas circunstâncias, podese aduzir preliminarmente que houve notória participação de crosta preexistente na sua evolução, em proporções semelhantes àquelas de materiais juvenis.

Estes resultados isotópicos para as metagrauvacas estão configurados na Figura 8, que mostra comportamento claro em dois grupos. O primeiro, mais abundante (direita do diagrama) estão configurando aquelas rochas com contribuição de fontes do embasamento, ainda que desde proporções diminutas. À esquerda do diagrama estão aquelas rochas onde a contribuição de materiais juvenis foi preponderante.

No tocante aos ortognaisses, a situação é um pouco diferente. Em mais de $70 \%$ dos casos o $\mathrm{T}_{\mathrm{DM}}$ calculado fica entre 2,0 e $1,5 \mathrm{Ga}$, e muito poucos (ca. $4 \%$ ) apresentam valores de idade acima disso (salvo exceções a serem comentadas); e mais, há um contingente com valores de $\mathrm{T}_{\mathrm{DM}}$ abaixo de $1,5 \mathrm{Ga}$ (cerca de15\%). No concernente ao $\varepsilon N d$, calculado para o Eoneoproterozóico, cerca de $\mathbf{7 4 \%}$ dos casos (bem mais do que no caso das metagrauvacas e xistos) os valores de ENd são positivos (8 casos!) ou fracamente negativos (superiores a-3). Todos os demais casos de $\boldsymbol{E}$ Nd podem ser considerados moderadamente negativos (entre $-4 \mathrm{e}-9$ ).

Nas Figuras 8 e 9 pode ser verificado o comportamento muito homogêneo das retas de evolução do $\mathrm{Nd}$ para os ortognaisses, ocupando uma área/posição intermediária

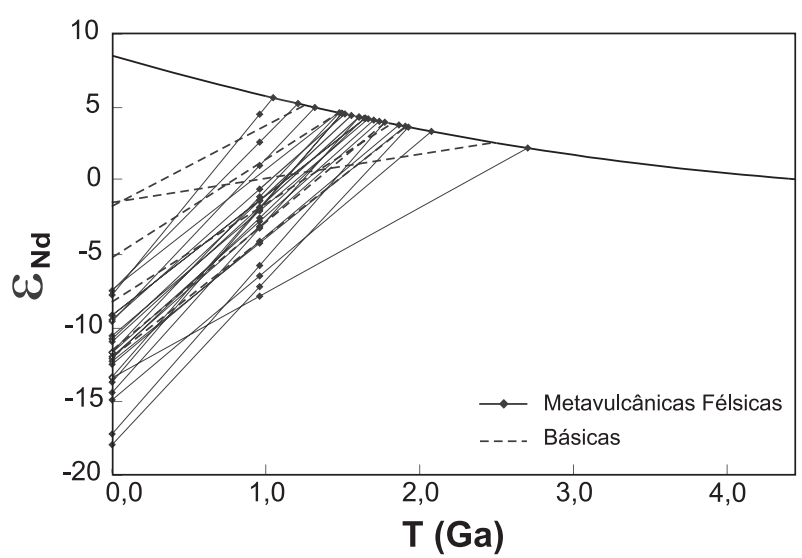

Figura 7. Diagrama de evolução isotópica do $\mathrm{Nd}$ para as rochas metassedimentares, metafélsicas e metabásicas do Terreno Riacho Gravatá - RG.

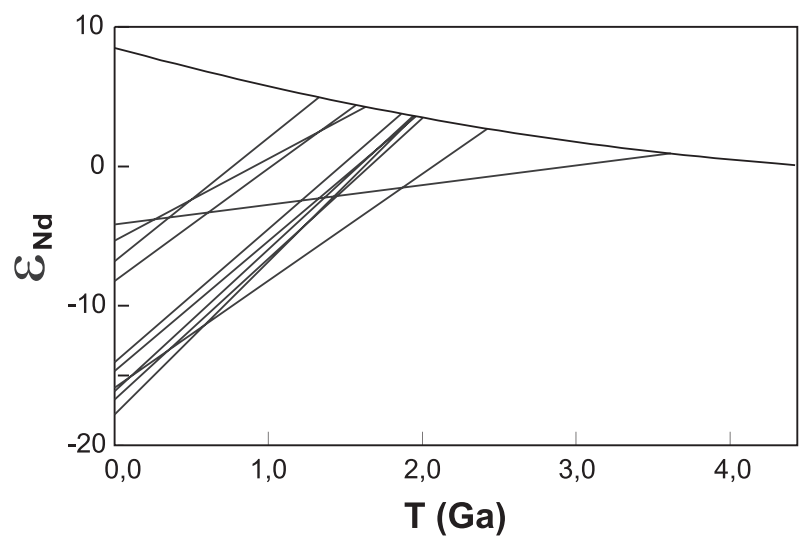

Figura 8. Diagrama de evolução isotópica do $\mathrm{Nd}$ para as metagrauvacas (com biotita e muscovita, às vezes com granada e sillimanita) e rochas metavulcânicas do Terreno Alto Pajeú (Complexo São Caetano).

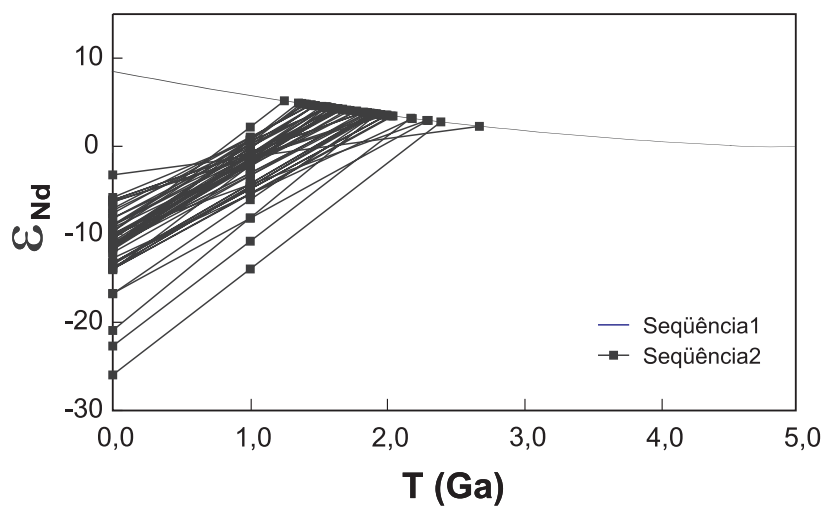

Figura 9. Diagrama de evolução isotópica do $\mathrm{Nd}$ para ortognaisses (biotita-muscovita gnaisses, às vezes com granada e turmalina) do Terreno Alto Pajeú - TAP. Os ortognaisses (ditos "Cariris Velhos") acham-se encaixados no Complexo São Caetano (vide Figura 1). 
Tabela 6. Dados analíticos das determinações Sm/Nd no Terreno/Faixa Riacho Gravatá - RG.

\begin{tabular}{|c|c|c|c|c|c|c|c|c|c|c|c|}
\hline Lab. $N^{\circ} / S P S$ & Localidade & Rocha & Sm/ppm & $\mathrm{Nd} / \mathrm{ppm}$ & ${ }^{147} \mathrm{Sm} /{ }^{144} \mathrm{Nd}$ & ${ }^{143} \mathrm{Nd} /{ }^{144} \mathrm{Nd}$ & Erro & $\varepsilon N d(0)$ & $\varepsilon N d(t)$ & $T_{D M(M a)}$ & Coordenadas \\
\hline $97-214$ & Piaus & metabas. & 6,185 & 30,041 & 0,12447 & 0,512025 & 0,000009 & $-11,96$ & $-2,72$ & 1727 & $9161500 / 605300$ \\
\hline 2113 & Piaus 2B & metabas. & 8,634 & 39,854 & 0,13100 & 0,512008 & 0,000014 & $-12,29$ & $-4,25$ & 1906 & $9161500 / 605300$ \\
\hline 2115 & Piaus 2T & metatufo & 7,337 & 34,549 & 0,12840 & 0,511998 & 0,000011 & $-12,48$ & $-4,12$ & 1865 & $9161500 / 605300$ \\
\hline 2122 & Piaus 1XV & xis.grafito. & 2,573 & 10,275 & 0,15140 & 0,511951 & 0,000016 & $-13,40$ & $-7,86$ & 2704 & $9161500 / 605300$ \\
\hline 2247 & Piaus 2A & metariolito & 11,124 & 61,807 & 0,10880 & 0,511717 & 0,000017 & $-17,97$ & $-7,21$ & 1928 & $9161500 / 605300$ \\
\hline $93-74$ & V-60Z & metariolito & 7,970 & 37,700 & 0,12786 & 0,511874 & - & $-14,90$ & $-5,22$ & 2075 & $9161500 / 605300$ \\
\hline $93-74 \# 2$ & $V-60 B$ & metariolito & 11,190 & 65,630 & 0,10312 & 0,511755 & - & $-17,22$ & $-4,06$ & 1773 & $9161500 / 605300$ \\
\hline 2118 & V-65 Man. & metafelsi. & 8,504 & 43,356 & 0,11860 & 0,512018 & 0,000013 & $-12,09$ & $-2,53$ & 1640 & $9151700 / 589250$ \\
\hline- & V-65 Man. & metafelsi. & 7,530 & 35,760 & 0,12732 & 0,512097 & 0,000015 & $-10,54$ & $-1,67$ & 1665 & $9151700 / 589250$ \\
\hline - & V-65\#2 & metafelsi. & 7,138 & 35,337 & 0,12212 & 0,512077 & 0,000012 & $-10,94$ & $-1,40$ & 1604 & $9151700 / 589250$ \\
\hline $95-229$ & Manaira & metatufo & 22,337 & 112,410 & 0,12010 & 0,512087 & 0,000010 & $-10,76$ & $-0,96$ & 1550 & $9151700 / 589250$ \\
\hline $95-231$ & W Manaira & metagrav. & 5,013 & 24,400 & 0,12420 & 0,512153 & 0,000014 & $-9,46$ & $-0,18$ & 1510 & $9153600 / 588000$ \\
\hline $95-232$ & W Manaira & metariolito & 2,713 & 15,940 & 0,10980 & 0,511954 & 0,000020 & $-13,35$ & $-2,23$ & 1590 & $9153600 / 588000$ \\
\hline $96-276$ & Pinheira & metariolito & 6,786 & 40,690 & 0,10080 & 0,511936 & 0,000016 & $-13,69$ & $-1,42$ & 1490 & $9153700 / 587800$ \\
\hline $96-277$ & Pinheira & metariolito & 2,200 & 10,010 & 0,13290 & 0,512169 & 0,000017 & $-9,15$ & $-0,99$ & 1640 & $9153700 / 587800$ \\
\hline $96-277 \# 2$ & Pinheira & metariolito & 3,064 & 13,930 & 0,13300 & 0,512169 & 0,000012 & $-9,15$ & $-1,00$ & 1640 & $9153700 / 587800$ \\
\hline 2117 & Pinh.(SPI) & metafelsi. & 5,992 & 34,416 & 0,10530 & 0,511899 & - & $-14,42$ & $-3,22$ & 1607 & $9153700 / 580790$ \\
\hline 96-NS3 & Quixadá & bolder fel. & 2,265 & 14,220 & 0,09630 & 0,512239 & 0,000015 & $-7,78$ & $5,12 ? ?$ & 1040 & $9145000 / 628800$ \\
\hline $97-208$ & Pé de Serra & metafel.? & 1,121 & 5,476 & 0,12374 & 0,512038 & 0,000013 & $-11,70$ & $-2,36$ & 1690 & $9205200 / 689400$ \\
\hline 2119 & Jurú 1 & metabas. & 5,159 & 21,565 & 0,14470 & 0,512368 & 0,000008 & $-5,27$ & $-0,26$ & 1485 & $9160000 / 629000$ \\
\hline $96-274$ & NW Man. & metabas. & 3,010 & 9,820 & 0,18550 & 0,512576 & 0,000014 & $-1,20$ & 0,23 & 2566 & $9150000 / 591200$ \\
\hline $96-278$ & Pau Ferro & gabro & 5,800 & 22,630 & 0,15490 & 0,512556 & 0,000017 & $-1,60$ & 3,76 & - & $9156000 / 582200$ \\
\hline $96-280$ & A. Vermel. & gabro & 5,060 & 22,980 & 0,13316 & 0,512263 & 0,000015 & $-7,32$ & 0,81 & 1473 & $9171400 / 588700$ \\
\hline $97-204$ & B. Canoas & metabas. & 1,645 & 6,854 & 0,14507 & 0,512220 & - & $-8,47$ & $-1,86$ & 1850 & $9169500 / 616000$ \\
\hline $95-211$ & Mocambo & hipoabisal & 4,947 & 27,170 & 0,11010 & 0,512147 & 0,000012 & $-9,59$ & $-2,95$ & 1310 & $7^{\circ} 31^{\prime}, 58 / 37^{\circ} 56^{\prime}, 94$ \\
\hline 3693 & $\mathrm{~N}$ Vassour. & metafels. & 6,501 & 23,322 & 0,16860 & 0,512153 & 0,000008 & $-9,46$ & $-6,02$ & 3100 & $9084842 / 490375$ \\
\hline 3694 & $\mathrm{~N}$ Vassour. & augen-gn. & 10,680 & 54,181 & 0,11920 & 0,511946 & 0,000008 & $-13,50$ & $-3,99$ & 1800 & $9084842 / 491396$ \\
\hline 3695 & Vassouras & leucogn. & 8,971 & 40,486 & 0,13400 & 0,512120 & 0,000009 & $-10,11$ & $-2,41$ & 1800 & $9081877 / 492960$ \\
\hline
\end{tabular}

Tabela 7. Dados analíticos das determinações Sm-Nd de metagrauvacas e xistos (Complexo São Caetano) do Terreno Alto Pajeú - TAP, trecho selecionado imediatamente ao sul da ZTTTN.

\begin{tabular}{|c|c|c|c|c|c|c|c|c|c|c|c|c|}
\hline Lab. $\mathbf{N}^{\circ}$ & Amostra & Localidade & Rocha & Sm & Nd & ${ }^{147} \mathrm{Sm} /{ }^{144} \mathrm{Nd}$ & ${ }^{143} \mathrm{Nd} /{ }^{144} \mathrm{Nd}$ & Erro & $\varepsilon N d(0)$ & $\varepsilon N d(t)$ & $T_{D M(M a)}$ & Coordenadas \\
\hline 2288 & P 5 & E SJEgito & m.bi-gn & 5,257 & 25,718 & 0,1236 & 0,511885 & 0,000012 & $-14,69$ & $-5,74$ & 1958 & $9173375 / 694479$ \\
\hline 2678 & Spp-35A & WSJEgito & mgv. & 6,825 & 37,237 & 0,1108 & 0,511726 & 0,000013 & $-17,79$ & $-7,27$ & 1951 & $9174006 / 688496$ \\
\hline 2294 & P-36B & WSJEgito & m.b.gna. & 3,409 & 15,090 & 0,1366 & 0,511824 & 0,000012 & $-15,88$ & $-8,52$ & 2423 & $9174448 / 686675$ \\
\hline 2112 & MGV-SJE & WSJEgito & mgv. & 3,415 & 11,121 & 0,1857 & 0,512425 & 0,000015 & $-4,15$ & $-2,81$ & 3618 & $9174006 / 688600$ \\
\hline 2679 & SppGn77 & NWSJEgito & mgv. & 22,253 & 89,335 & 0,1506 & 0,512365 & 0,000017 & $-5,33$ & 0,32 & 1632 & $9180694 / 690674$ \\
\hline 2405 & Spp-JS & J. Silva & mgv. & 8,130 & 36,789 & 0,1336 & 0,512217 & 0,000074 & $-8,21$ & $-0,49$ & 1568 & $9190806 / 777381$ \\
\hline 2677 & Spp SWT & Sul Teix. & mgv. & 5,952 & 28,259 & 0,1274 & 0,512289 & 0,000013 & $-6,81$ & 1,68 & 1329 & $9180694 / 690674$ \\
\hline 2290 & $\mathrm{P}-17$ & Rc. Salgad. & m.-b.gna. & 7,297 & 36,257 & 0,1217 & 0,511917 & 0,000013 & $-14,06$ & $-4,88$ & 1864 & $9176437 / 701695$ \\
\hline 2291 & $\mathrm{P}-26 \mathrm{~A}$ & Felipe & m.-b.gna. & 9,733 & 50,296 & 0,1170 & 0,511812 & 0,000016 & $-16,11$ & $-6,36$ & 1940 & $9175254 / 694872$ \\
\hline
\end{tabular}


Tabela 8. Dados analíticos das determinações $\mathrm{Sm}-\mathrm{Nd}$ dos ortognaisses (ditos Cariris Velhos) e migmatitos do Terreno Alto Pajeú - TAP, trecho selecionado imediatamente ao sul da ZTTTN.

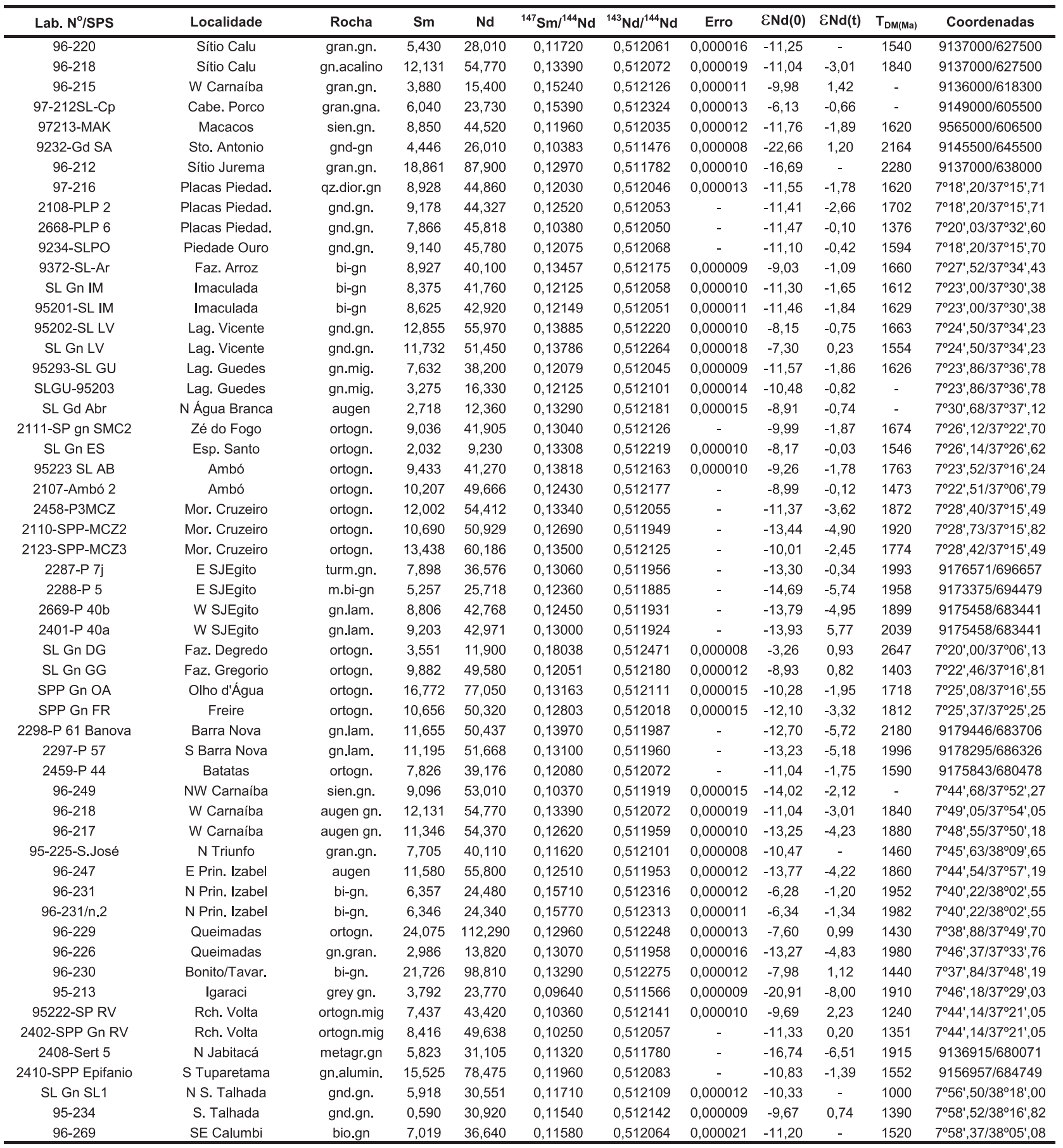


Tabela 9. Dados analíticos das determinações Sm-Nd do TAP, entre Flores e Tabira - PE. Área de valores considerados "anômalos".

\begin{tabular}{|c|c|c|c|c|c|c|c|c|c|c|c|}
\hline Lab. N/SPS & Localidade & Rocha & Sm/ppm & $\mathrm{Nd} / \mathrm{ppm}$ & ${ }^{147} \mathrm{Sm} /{ }^{144} \mathrm{Nd}$ & ${ }^{143} \mathrm{Nd} /{ }^{144} \mathrm{Nd}$ & Erro & $\varepsilon N d(0)$ & $\varepsilon N d(t)$ & $\mathrm{T}_{\mathrm{DM}(\mathrm{Ma})}$ & Coordenadas \\
\hline $96-227$ & Lagoa da Cruz & bi-gnais. & 3,167 & 15,88 & 0,12060 & 0,511530 & 0,000009 & $-21,62$ & $-2,09$ & 2470 & $9147000 / 625000$ \\
\hline $96-204$ & NW Afog. Ing. (Serrinha) & bi-gnais. & 4,239 & 26,51 & 0,09670 & 0,511436 & 0,000011 & $-23,44$ & 2,26 & 2080 & $9150000 / 646000$ \\
\hline $93-32$ & Sto. Antonio & gnd-gn & 4,446 & 26,01 & 0,10383 & 0,511476 & 0,000008 & $-22,66$ & 1,20 & 2164 & $9144700 / 644500$ \\
\hline $96-215$ & W Carnaíba & gran.gn. & 3,880 & 15,40 & 0,15240 & 0,512126 & 0,000011 & $-9,98$ & 1,42 & 2160 & $9136500 / 627200$ \\
\hline $96-212$ & Sítio Jurema (SE Carnaíba) & gran. & 18,861 & 87,90 & 0,12970 & 0,511782 & 0,000010 & $-16,69$ & 0,51 & 2280 & $9137300 / 638000$ \\
\hline
\end{tabular}

entre o primeiro e o segundo grupo das metagrauvacas. Uma parte das amostras está sinalizando para comportamento de rochas derivadas de materiais com pouca ou nenhuma residência crustal prévia, passando daí para rochas onde é maior a participação de componentes crustais mais antigos. Esta posição de maior parte das retas (dos gnaisses) entre aqueles dois grupos (das metagrauvacas) sinaliza favorável para uma observação preliminar de campo, de que parte, pelo menos, dos gnaisses pode ter se formado por fusão das metagrauvacas.

Fica assim demonstrado, e deve ser reiterado, que são notórias as evidências de participação de materiais juvenis nas unidades litológicas principais do TAP, como já o fora no PAB e RG. Há diferenças de comportamento entre estas principais unidades litológicas do TAP que podem ser cotejadas na observação das Figuras 8 (metagrauvacas e xistos) e 9 (gnaisses diversos).

$\mathrm{Na}$ área ao norte de Afogados de Ingazeira, entre Flores e Tabira (incluindo o batólito de Solidão) há uma área/trecho de comportamento anômalo (Tabela 9) em relação ao que foi discutido acima para os ortognaisses, e com valores e dados que mais se aproximam daqueles do embasamento paleoproterozóico aflorante (como já visto em São José do Caiano e ao norte de Serra Talhada, e que será visto no TAM). É oportuno e necessário acrescentar que os ortognaisses são do Cariris Velhos (litologia e geocronologia $\mathrm{U}-\mathrm{Pb}$ ) e que tectônica tangencial do Cariris Velhos e Brasiliana tem sido claramente reconhecida nestas unidades lito-estruturais. Ainda pode ser adiantado que isto não é fenômeno isolado, posto que na projeção oriental do TAP, outros setores de comportamento assim distinto (dito "anômalo") como este já foram reconhecidos (área sul da folha Guarabira, por exemplo, Brito Neves, em preparação).

Há mais de uma possibilidade de interpretação próximas entre si, na falta do detalhamento que se faz necessário. É possível que isto esteja representando uma extensão para o sul das condições de embasamento a serem discutidas para a ZTTTN, com algum tipo de continuidade preexistente. Outra possibilidade (com mais chance de ser verdadeira) é a da presença substancial de um fragmento da colagem paleoproterozóica (fragmento/lasca do TAM) no embasamento do TAP, naquela área mencionada.
Agora é oportuno evocar o contexto de valores de dados isotópicos do $\mathrm{Nd}\left(\mathrm{T}_{\mathrm{DM}}, \boldsymbol{E} \mathrm{Nd}\right.$ etc.) dominantes no TAP, com posição ao sul da ZTTTN, e confrontá-los com aqueles ao norte, domínios de RG e PAB, e mais ainda com os valores ao longo da ZTTTN. Fica evidente o zoneamento isotópico da Zona Transversal, com sítios/espaços de evolução geológica distintas, com semelhanças interessantes entre aquelas separadas pela ZTTTN.

Além do mais, todos os valores de $\mathrm{T}_{\mathrm{DM}}$ mais elevados (entre 2,0 e 2,6 Ga) e os demais dados "anômalos" assinalados no TAP carecem de revisão, tanto do ponto de vista geológico como com o auxílio de outros métodos geocronológicos. Por fim, é necessário e válido ressaltar que tanto no TAP, como no RG e PAB, foi feita alusão à presença (com maior ou menor ênfase) de resíduos crustais e/ou fontes de residência paleoproterozóica, mas que sempre em condições subalternas àquelas que propiciavam derivação juvenil.

\section{PLUTÕES DO CORTEJO BRASILIANO PRINCIPAL DA ZTTTN}

(Tabela 10, Figuras 10, 11 e 12)

Como enfatizado desde o início, este cortejo de rochas graníticas brasilianas reúne praticamente todos os tipos clássicos de ocorrências da Borborema (caso da Zona Transversal, vide Santos e Medeiros, 1999; Ferreira et al., 2004), ao longo de uma zona linear de cerca de $450 \mathrm{~km}$, que perlonga o limite entre o RG e o TAP. Estes granitos e sienitos aparecem intrudindo rochas do TAP (principalmente) e o do RG (sul do RG), e em parte do embasamento deles.

Há uma notável coerência na análise dos dados de evolução de $\mathrm{Nd}$ apresentados, e isto está consignado na análise da Figura 10.

O primeiro grupo a destacar são os de valores ditos excepcionais a este conjunto, que são de amostras coletadas no batólito de Tavares (duas localidades distintas), numa das localidades do sienito de Terra Nova, que ficam na parte mais à esquerda da Figura 11. A reta do xenólito piroxenítico, de caráter mantélico assegurado, de Triunfo cruza diagonalmente este primeiro conjunto de retas de rochas, onde a influência de fontes crustais e litosféricas 
preexistentes é decisivamente menor. Estas rochas do primeiro conjunto se destacam do outro conjunto à direita do diagrama, devido aos valores de $\mathcal{E N d}(\mathrm{t})$ fracamente negativos, com idades $\mathrm{T}_{\mathrm{DM}}$ do Mesoproterozóico e do Paleoproterozóico Superior.

O segundo grupo a destacar, mais à direita do diagrama, que inclui as demais graníticas da ZTTTN, é muito homogêneo, com valores de $\varepsilon \mathrm{Nd}(0)$ fortemente negativos, e a grande maioria de idades dentro do intervalo das partes média a superior do Paleoproterozóico, com gama considerável de variação. Este segundo conjunto é surpreendente pela relativa homogeneidade de comportamento, por ser relativo a litotipos diversos de incontestável idade neoproterozóicas (plutões entre $650 \mathrm{e}$ $570 \mathrm{Ma}$ ). E quando este conjunto é comparado com aquele do embasamento aflorante (Figura 4), verifica-se que estas retas estão arranjadas flagrantemente mais acima e em paralelo com aquelas retas consignadas na Figura 4 (referente a rochas do norte de Serra Talhada). A participação de materiais continentais na formação das rochas graníticas se configura ainda mais claramente neste segundo conjunto de retas subparalelas porque ele fica abaixo do primeiro conjunto (onde a maior participação de materiais juvenis foi já reiterada).

Estes dados são muito importantes porque mostram que havia heterogeneidade no embasamento (não era isótropo e monolítico), e que não era radicalmente contínua a fonte de contaminação destas rochas plutônicas, todas elas inequivocamente do Neoproterozóico (dados U-Pb e Rb-Sr disponíveis, por vários autores, todos referidos).

No cômputo geral, a maioria inconteste dos valores de $\mathrm{T}_{\mathrm{DM}}$ apontam para tempos do Paleoproterozóico, com semelhança notória com aqueles das diversas unidades do embasamento (Serra Talhada, o TAM e de São José do Caiano, já discutidos). Os valores de $\mathcal{E} \mathrm{Nd}$ para o Neoproterozóico são mediana a fortemente negativos (inferiores a-10, em mais de $70 \%$ dos casos), elevados para rochas ígneas, salvo as exceções acima citadas, chegando a lembrar os valores de rochas graníticas ocorrentes no embasamento paleoproterozóico e arqueano do RGN (em Dantas, 1997).

A hipótese de trabalho proposta é a de uma faixa aproximadamente linear e relativamente estreita de embasamento paleoproterozóico em grande parte não aflorante e subaflorante, intermediária a dois espaços tectônicos distintos (a sul, o TAP e a norte, $\mathrm{RG}+\mathrm{PAB}$ ), com algumas descontinuidades de extensão e de espessura litosférica. Esta hipótese de uma zona de embasamento subaflorante, mais ou menos intermediária a duas outras áreas de embasamento francamente exposto (SJC e TAM) está esquematizada na Figura 11.

Para o caso dos sienitos peralcalinos ultrapotássicos, a interpretação dada por Ferreira et al. (2004) é da derivação de uma fonte mantélica (paleoproterozóica) enriquecida em elementos incompatíveis. Dentro desta linha de raciocínio, diante da natureza e do conhecimento petrológico e geoquímico destas rochas, pode-se acrescentar a hipótese que, localmente, frações do manto litosférico estavam acoplados a esse cortejo aproximadamente contínuo de basement inliers subjacentes, do Paleoproterozóico. Estas rochas sieníticas ultrapotássicas apresentam características de intrusivas tardi-orogênicas a pós-orogênicas, e sua ascensão e colocação nos níveis crustais atuais devem estar condicionadas por descontinuidades estruturais importantes (pré-extrusão ou cedo-extrusão).

A reunião privilegiada de tratos crustais e eventualmente litosféricos paleoproterozóicos (alguns tratos lito-estruturais mais antigos podem estar consorciados) no substrato dos terrenos Cariris Velhos como evidenciado pelos dados isotópicos e geológicos pode ser devido à várias causas, admite várias conjecturas a nível subcrustal e crustal. A tectônica contracional, muito evidente ao longo e ao largo de todo o TAM, pode ser utilizada para explicar esta condição tectônica, ou seja, poderia ser uma estruturação que repete o sliver do TAM, incluindo tratos do manto litosférico, em condição rasa, subaflorante. A linearidade de corpos graníticos cálcio-alcalinos de alto potássio do Neoproterozóico pode estar indicando um arco magmático (conforme ilustrado no cartoon, Figura 12), produto da subducção do trato oceânico outrora subjacente às rochas do PAB.

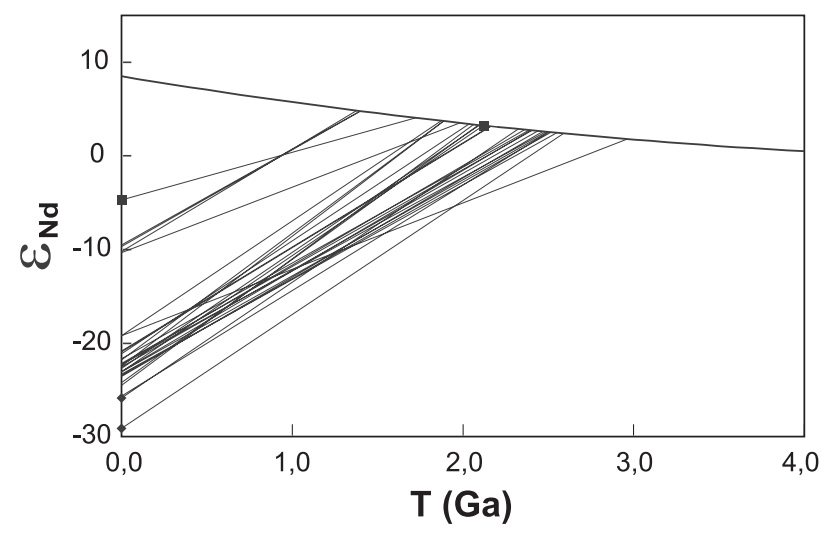

Figura 10. Diagrama de evolução isotópica do $\mathrm{Nd}$ para as diferentes rochas plutônicas (e algumas rochas fissurais) do cortejo intrusivo da ZTTTN, de Teixeira - PB a Terra Nova - PE. Vide Figura 1 e Quadro 1. 
Tabela 10. Dados analíticos das determinações $\mathrm{Sm} / \mathrm{Nd}$ dos plutões graníticos e sieníticos neoproterozóicos ao longo da ZTTTN.

\begin{tabular}{|c|c|c|c|c|c|c|c|c|c|c|c|}
\hline Lab. Nº'SPS & Localidade & Rocha & Sm/ppm & $\mathrm{Nd} / \mathrm{ppm}$ & ${ }^{147} \mathrm{Sm} / /^{144} \mathrm{Nd}$ & ${ }^{143} \mathrm{Nd} /{ }^{144} \mathrm{Nd}$ & Erro & $\varepsilon N d(0)$ & $\varepsilon N d(t)$ & $T_{D M(M a)}$ & Coordenadas \\
\hline 9235-SLGtx & Teixeira & gran. & 4,700 & 27,780 & 0,10232 & 0,511555 & 0,000012 & $-21,13$ & $-13,90$ & 2036 & $9198500 / 694000$ \\
\hline 95-204 & Palmeira & leucogran. & 2,138 & 11,790 & 0,10960 & 0,511570 & 0,000012 & 20,83 & $-14,18$ & 2150 & $9183500 / 652000$ \\
\hline $95-225$ & B. Vista & gran. & 7,750 & 40,110 & 0,11620 & 0,512101 & 0,000008 & $-10,47$ & $-4,30$ & 1460 & $9143500 / 592500$ \\
\hline $95-226$ & B. Vista & dique fels. & 9,210 & 47,780 & 0,11650 & 0,511527 & 0,000008 & $-21,68$ & $-15,56$ & 2370 & $9143500 / 592500$ \\
\hline $95-204 \# 2$ & Palmeira & leucogran. & 2,138 & 11,800 & 0,10956 & 0,511566 & 0,000012 & $-20,90$ & $-14,25$ & 2167 & $9183500 / 652000$ \\
\hline $96-228$ & Tavares & gran. & 4,554 & 23,660 & 0,11640 & 0,512150 & 0,000010 & $-9,51$ & $-3,36$ & 1390 & $9155000 / 622500$ \\
\hline $96-228 \# 2$ & Tavares & gran. & 4,508 & 23,560 & 0,11670 & 0,512142 & 0,000012 & $-9,68$ & $-3,54$ & 1410 & $9155000 / 622500$ \\
\hline 92-31-SLSyTR & Triunfo & sienito & 5,560 & 29,030 & 0,11583 & 0,511483 & 0,000012 & $-22,53$ & $-16,53$ & 2439 & $9134000 / 598500$ \\
\hline 95-224-Sy & Triunfo & sienito & 5,940 & 31,920 & 0,11250 & 0,511459 & 0,000011 & $-23,00$ & $-16,57$ & 2380 & $9135000 / 602500$ \\
\hline 95224-px & Triunfo & xenol. pirox. & 5,491 & 21,170 & 0,15679 & 0,512396 & 0,000010 & $-4,72$ & $-1,67$ & 1717 & $9135000 / 602500$ \\
\hline $95-228$ & Manaira & dique fels. & 7,949 & 40,570 & 0,11846 & 0,511497 & 0,000008 & $-22,26$ & $-16,28$ & 2470 & $9148500 / 593500$ \\
\hline $95-230$ & Manaira & dique fels. & 9,602 & 49,890 & 0,11636 & 0,511457 & 0,000008 & $-23,03$ & $-16,90$ & 2479 & $9148500 / 593500$ \\
\hline $95-233$ & Prin. Izabel & dique fels. & 6,626 & 39,790 & 0,10069 & 0,511655 & 0,000010 & $-19,18$ & $-11,83$ & 1862 & $9145000 / 611000$ \\
\hline SLGpPIZ & Prin. Izabel & gran. & - & - & - & - & - & $-3,50$ & - & 1454 & $9145000 / 610000$ \\
\hline 3698 & Pajeú/04-20 & sienito & 6,683 & 49,205 & 0,08210 & 0,511279 & 0,000024 & $-26,51$ & $-18,04$ & 2000 & $9099151 / 564985$ \\
\hline 3699 & Pajeú/04-21 & sienito & 9,129 & 65,856 & 0,08380 & 0,511228 & 0,000008 & $-27,50$ & $-19,15$ & 2100 & $9109341 / 596655$ \\
\hline $95-236$ & Serra Casé & ultrapot. & 10,900 & 56,910 & 0,11682 & 0,511437 & 0,000011 & $-23,43$ & $-17,33$ & 2524 & $9091000 / 456700$ \\
\hline $95-236 \# 2$ & Serra Casé & ultrapot. & 9,024 & 46,460 & 0,11742 & 0,511443 & 0,000013 & $-23,31$ & $-17,26$ & 2530 & $9091000 / 456700$ \\
\hline $95-237$ & Terra Nova & dique $\mathrm{H}-\mathrm{K}$ & 13,942 & 74,220 & 0,11356 & 0,511431 & 0,000010 & $-23,55$ & $-17,20$ & 2449 & $9091000 / 456700$ \\
\hline $95-238$ & Terra Nova & sienito & 11,140 & 60,660 & 0,11103 & 0,512114 & 0,000011 & $-10,22$ & $-3,65$ & 1371 & $9090000 / 459000$ \\
\hline SLSyTN & Terra Nova & sienito & - & - & 0,08960 & - & - & $-21,70$ & $-13,50$ & 1860 & $9090000 / 459000$ \\
\hline- & Serra Man & - & - & - & - & - & - & - & $-17,00$ & 2300 & $38^{\circ} 44^{\prime}, 00 / 08^{\circ} 20^{\prime}, 00$ \\
\hline
\end{tabular}

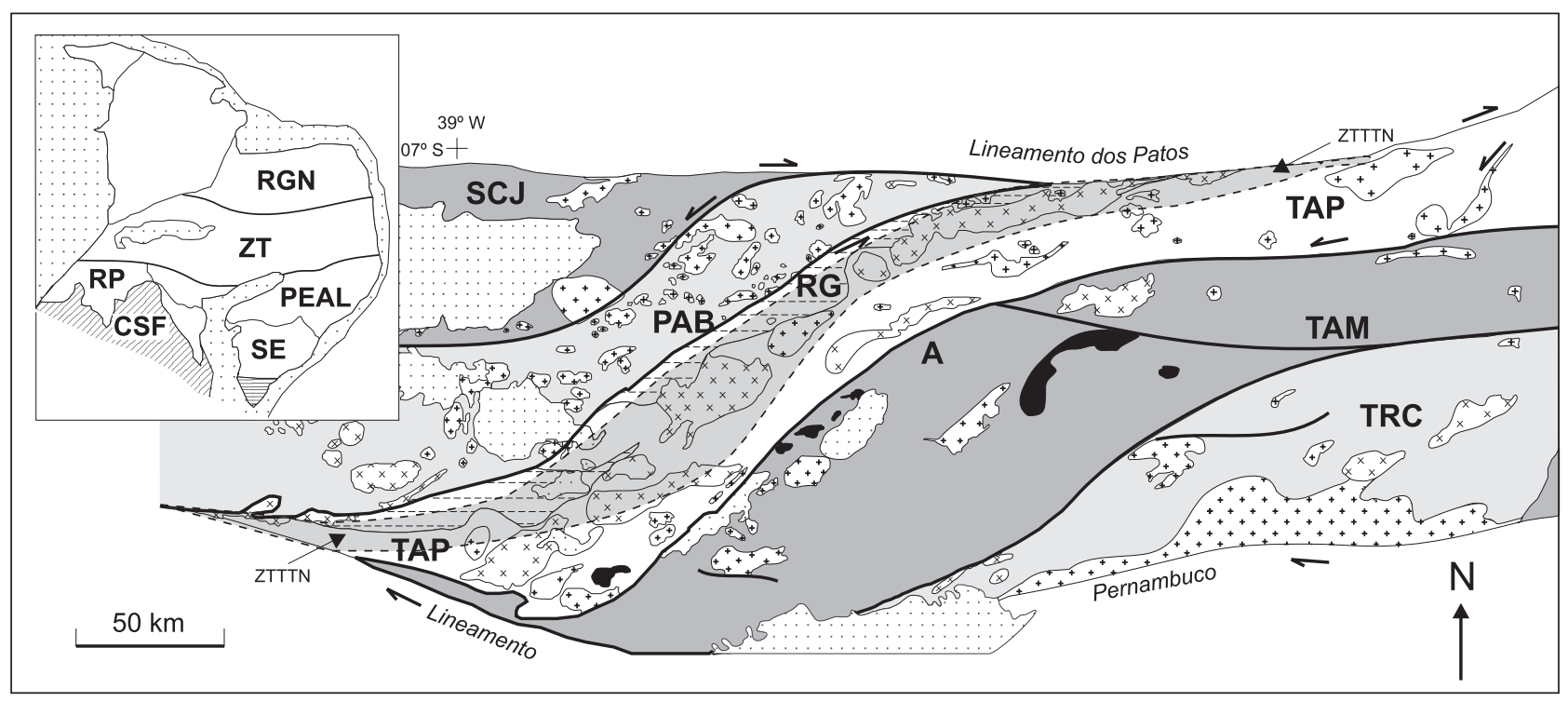

Figura 11. Representação esquemática do domínio da ZTTTN, disposta em forma quase diagonal ao retângulo da Zona Transversal. Ao norte e ao sul da zona sombreada, o comportamento isotópico dos terrenos/rochas é francamente distinto, como discutido no texto. Observar que esta zona está delineada ao norte do TAP, e que ela divide ao meio o espaço da Zona Transversal entre dois domínios (TAM e SJC) de exposições francas do embasamento paleoproterozóico. 


\section{A) $\leqslant 960 \mathrm{Ma}$}

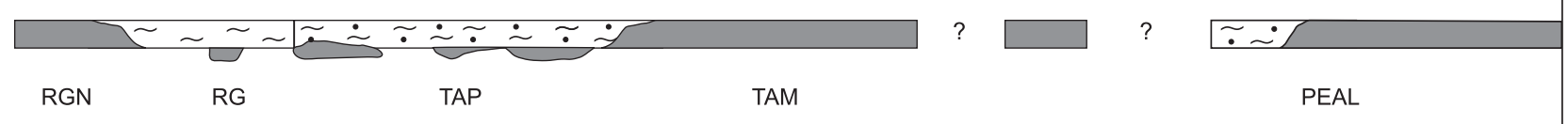

B) $\geqslant 650 \mathrm{Ma}$

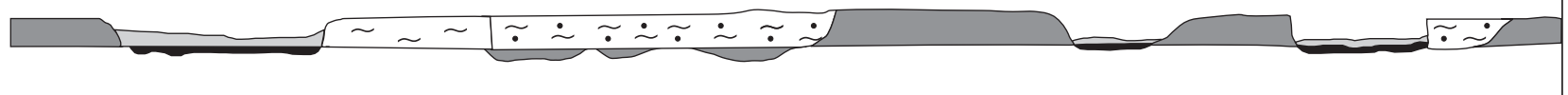

C) $640-570 \mathrm{Ma}$

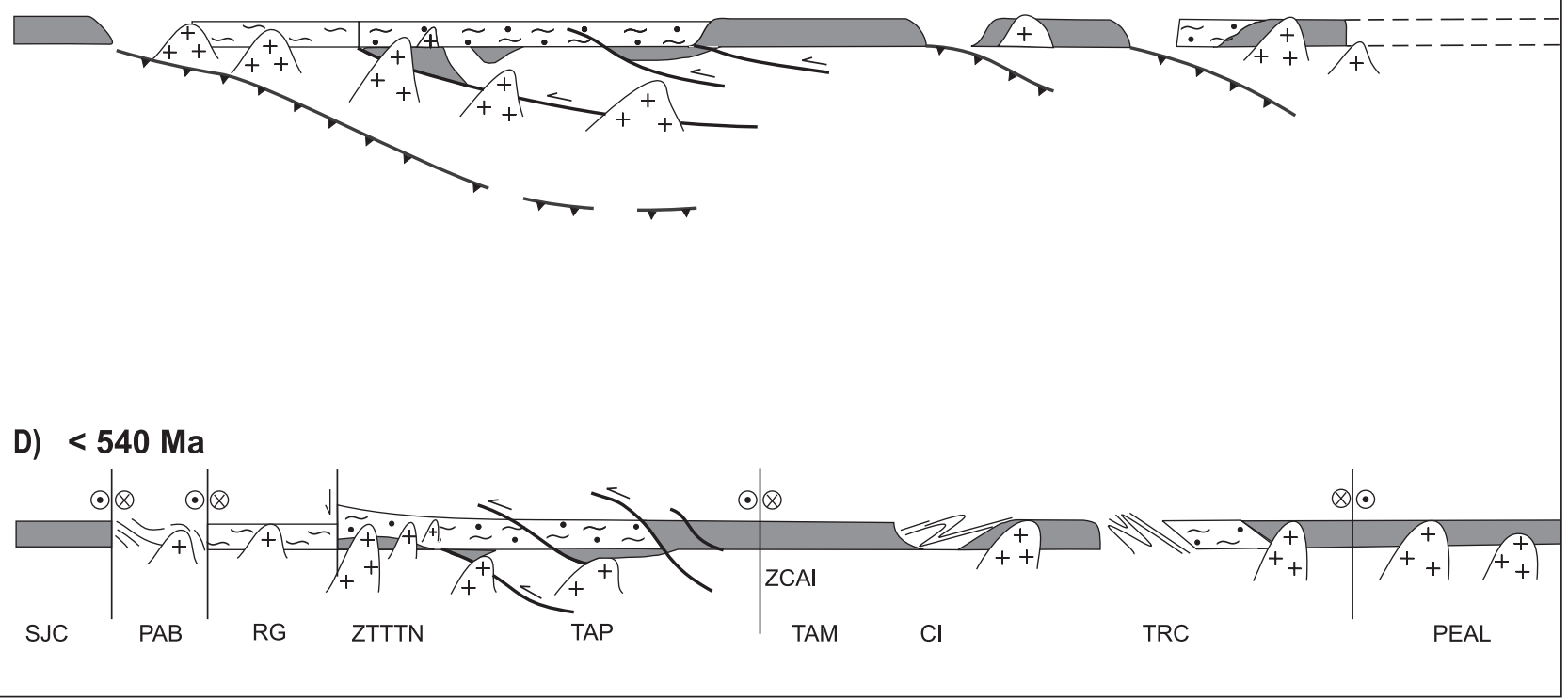

Figura 12. Cartoon simulando em 4 estágios simplificados a evolução proposta para a ZTTTN no interior da Zona Transversal:

A. na primeira metade do Toniano $(\geq 930 \mathrm{Ma}$ ), final do Ciclo Cariris Velhos, observar a presença de frações litosféricas paleoproterozóicas sob o TAP e o RG, idênticas àquelas aflorantes em RGN e TAM;

B. no final do Criogeniano ( $\geq 630 \mathrm{Ma}$ ), instalação de bacias sedimentares, em parte sobrejacentes à crosta oceânica, pelo menos em três tratos distintos: do PAB, na área de Irajaí ( $\mathrm{Cl}$ - Complexo Irajaí) e do RC;

C. no Ediacarano, inserção do plutonismo sinorogênico (640 - $620 \mathrm{Ma})$ e tardi-orogênico (580 - $570 \mathrm{Ma})$ privilegiando a área entre o RG e TAP, lugar geométrico-geológico da ZTTTN;

D. panorama do final Neoproterozóico-Cambriano, com a consolidação dos tratos orogênicos de Santana dos Garrotes (PAB), Irajaí (Cl) e Rio Capibaribe (RC) e as ações extrusionais promovidas pelas zonas de cisalhamentos laterais (Pernambuco, Patos) e internas (Boqueirão dos Coxos, Serra dos Caboclos e outras) da Zona Transversal. 
Entretanto, especular sobre estas causas e forma deste substrato paleoproterozóico (e sobre o período orogênico) sem um suporte adequado de levantamentos geofísicos (em escala de detalhe a semidetalhe) é um procedimento de risco, do qual estamos cientes e sujeitos, quando para o qual apresentamos uma proposição preliminar de modelo esquemático, no aguardo de informações imprescindíveis da terceira dimensão.

Independente deste desconhecimento (demandas que permanecem em aberto e que devem ser perquiridas) de causa e tempo, diante dos dados expostos fica evidenciado um novo tipo de participação de basement inliers da colagem paleoproterozóica na costura orogênica da Borborema, que persistiu durante pelo menos dois ciclos (Cariris Velhos e Brasiliano). Este tipo aqui proposto de ocorrência de fração do embasamento paleoproterozóico difere flagrantemente dos outros fragmentos francamente expostos do embasamento da colagem paleoproterozóica (tipo RGN, São José do Caiano,TAM etc.) por várias razões:

a. pelo maior grau de retrabalhamento tectônico-termal;

b. pela posição predominante não aflorante ou subaflorante;

c. pela intrigante propensão para alinhar granitos - de mais de uma etapa da evolução do Brasiliano, sinorogênicos (arco magmático, 640 - 620 Ma?) e tardi-orogênicos (rifte?, extrusão?, 580 - $570 \mathrm{Ma)}$ )

d. pela condição de ter sido melhor revelado somente graças a utilização de dados isotópicos $\mathrm{Sm}-\mathrm{Nd}$;

e. finalmente por sediar o lugar geométrico de um dos eixos de arqueamento cenozóico principais da Borborema.

Têm sido comuns na literatura da Borborema alusões a "manto metassomatizado" do "Transamazônico" para explicar estes fatos. A metassomatização do manto não pode explicar as exceções detectadas e a similaridade flagrante destes dados para com aqueles de outras áreas de embasamento paleoproterozóico (São José do Caiano, Serra Talhada, TAM etc.). A designação de "Transamazônico" ao invés de Paleoproterozóico é indevida, por uma série de razões outras pertinentes aos códigos de nomenclatura (vários itens) e ao bom-senso.

A interpretação e concepção de uma zona/"alto" do embasamento paleoproterozóico (com núcleos arqueanos prováveis menores), ou de um contexto da colagem paleoproterozóica mais preservado de estiramento (promovido ao longo dos ciclos Cariris Velhos e Brasiliano) é a mais simples, e ao nosso ver, a mais adequada. Esta zona estaria pois consubstanciando um domínio de embasamento distinto (crosta mais espessada e relativamente mais contínua, localmente com tratos do manto litosférico acoplados). E por assim ser, foi o lugar geométrico-geológico divisório e distinto dos espaços tectônicos do embasamento das faixas eoneoproterozóicas (RG, TAP) e neoproterozóica (PAB), onde o estiramento foi maior e a contribuição de fontes juvenis se verificou com freqüência.

A identificação e apresentação de um elemento do embasamento da colagem paleoproterozóica nesta maneira pouco usual (poucos afloramentos, descontinuidade em área, maior parte de indicações indiretas através de plutões diversos) no interior de uma província brasiliana constitui o cerne deste trabalho. Embora este não seja um quadro final do conhecimento, e haja muitas questões aguardando equacionamento e solução, esta é a hipótese de trabalho abraçada. A demanda por pesquisas futuras, geológicas, isotópicas e geofísicas pode ter nesta hipótese um ponto de partida.

$\mathrm{Na}$ zona imediatamente a leste do granito de Teixeira encontramos alguns ortognaisses (entremetidos no TAM) com características isotópicas ainda semelhantes àquelas do embasamento do ZTTTN. Mais para leste, onde ocorre o longo Batólito de Esperança (Archanjo e Fetter, 2004), o comportamento é diferente, o que parece assinalar que esta ZTTTN não vai para leste além do meridiano $36^{\circ} 00^{\prime}$.

\section{REFERÊNCIAS BIBLIOGRÁFICAS}

ARAÚJO, J. M. M.; GUIMARÃES, I. P.; GALINDO, A. C. Granitogênese Brasiliana no extremo NW da Faixa PajeúParaíba (PE/PB): o Complexo Granítico de Solidão. In: CONGRESSO BRASILEIRO DE GEOLOGIA, 39., 1996, Salvador. Anais... Salvador: Sociedade Brasileira de Geologia, 1996. v. 6, p.336-340 .

ARAÚJO, J. M. M.; GUIMARÃES, I. P.; GALINDO, A. C. Magmatismo de afinidade cálcio-alcalino no extremo NW do Terreno Alto Pajeú (TAP): Complexo Granítico Tabira (CGT), características de campo, petrográficas e geoquímicas. In: SIMPÓSIODE GEOLOGIADONORDESTE, 17., 1997, Fortaleza. Resumos expandidos. Fortaleza: Sociedade Brasileira de Geologia-Núcleo Nordeste, 1997. Boletim n. 15, p. 249-253.

ARCHANJO, C. J.; FETTER, A. Emplacement setting of the granite sheeted pluton of Esperança (Brasiliano Orogen, Northeastern Brazil). Precambrian Research, v. 135, p. 193-215, 2004.

BITTAR, S. M. B. Faixa Piancó-Alto Brígida: terrenos tectono-estratigráficos sob regimes metamórficos e deformacionais contrastantes. 1998. 126 p. Tese (Doutorado) - Instituto de Geociências, Universidade de São Paulo, São Paulo, 1998. 
BRASILINO, R. G.; SIAL, A. N.; LAFON, J. M. Magmatic epidote-hornblende barometric estimates, and emplacement of the Conceição das Creoulas Pluton, Alto Pajeú Terrane, NE Brazil. Anais da Academia Brasileira de Ciências, v. 71, n. 1,p. 3-16, 1999.

BRITO NEVES, B. B.; CAMPOS NETO, M. C.; VAN SCHMUS, W. R.; SANTOS, E. J. O sistema PajeúParaíba e o Maciço São José do Campestre no Leste da Borborema. Revista Brasileira de Geociências, v. 31, n. 2, p. 173-184, 2001a.

BRITO NEVES, B. B.; CAMPOS NETO, M. C.; VAN SCHMUS, W. R.; FERNANDES, T. M. G.; SOUZA, S. L. O terreno Alto Moxotó no Leste da Paraíba (Maciço Caldas Brandão). Revista Brasileira de Geociências, v. 31, n. 2, p.185-194, 2001b.

BRITO NEVES, B. B.; PASSARELLI, C. R.; BASEI, M. A. S.; SANTOS, E. J. Idades U-Pb em zircão de alguns granitos clássicos da Província Borborema. Geologia USP. Série Científica, v. 3, p. 25-38, 2003.

BRITO NEVES, B. B.; SANTOS, E. J.; VAN SCHMUS, W. R. Tectonic History of the Borborema Province. In: CORDANI, U. G.; MILANI, E. J.; THOMAZ FILHO, A.; CAMPOS, D. A . (Ed.). Tectonic evolution of South America. Rio de Janeiro: [s.n.], p.151-182, 2000.

BRITO NEVES, B. B.; VAN SCHMUS, W. R.; SANTOS, E. J.; CAMPOS NETO, M. C. O evento Cariris Velhos na Província Borborema; integração de dados, implicações e perspectivas. Revista Brasileira de Geociências, v. 25, n. 4, p. 279-296, 1995.

CAMPOS NETO, M. C.; BRITO NEVES, B. B.; BITTAR, S. M. B. Domínio tectônico Rio Pajeú-Província Borborema: orogêneses superpostas no ciclo Brasiliano/Pan Africano. In: CONGRESSO BRASILEIRO DE GEOLOGIA, 38., 1994, Camboriú. Boletim de resumos expandidos. Camboriú: Sociedade Brasileira de Geologia, 1994. v. 1 (Simpósios), p. 221-222.

CZAJKA, W. Estudos geomorfológicos no Nordeste Brasileiro. Revista Brasileira de Geografia, v. 20, n. 2, p.135-178, 1958.

DANTAS, E. L. Geocronologia U-Pb e Sm-Nd de terrenos arqueanos e paleoproterozóicos do Maciço Caldas Brandão, NE do Brasil. 1997. 208 p. Tese (Doutorado)Instituto de Geociências e Ciências Exatas, UNESP, Rio Claro, 1997.
ENCINAS, C. N. R. Petrologia e Geoquímica do setor oeste do Batólito Pajeú, Terreno Alto Pajeú, Serra TalhadaPernambuco, Brasil. 1996. 174 p. Dissertação (Mestrado) Instituto de Geociências, Universidade de São Paulo, São Paulo, 1996.

FERREIRA, M. A. F.; FERREIRA, V. P.; SIAL, A. N.; PIMENTEL, M. M. Origin and intensive parameters in the crystallization of ultrapotassic syenites: the Serra do Man Pluton, Northeaster Brazil. Gondwana Research, v. 5, n. 2, p.275-285, 2002.

FERREIRA, V. P. Petrology and geochemistry of the Late Precambrian Ultrapotassic Peralkaline Triunfo Pluton and Related Dikes, State of Pernambuco, Northeast Brazil. 265 p. 1991. Thesis (Doctoral) - University of Georgia, Department of Geology, Athens, USA, 1991.

FERREIRA, V. P.; SIAL,A. N.; PIMENTEL, M. M.; MOURA, C. A. V. Intermediate to acidic magmatism and crustal evolution in the Trasnversal Zone. In: MANTESSO NETO, V.; BARTORELLI, A.; CARNEIRO, C. R.; BRITO NEVES, B. B. (Ed.). Geologia do Continente Sul-Americano: evolução da obra de Fernando Flávio Marques de Almeida. Beca: São Paulo, 2004. p. 189-202.

FERREIRA, V. P.; SIAL, A. N.; JARDIM DE SÁ, E. F. Geochemical and isotopic signatures of Proterozoic granitoids in terranes of the Borborema Structural Province, Northeast Brazil. Journal of South American Earth Sciences, v. 11, n. 5, p. 439-455, 1998.

GUIMARÃES, I. P.; SILVA FILHO, A. F.; ALMEIDA, C. N.; VAN SCHMUS, W. R.; ARAUJO, J. M. M.; MELO, S. C.; MELO, E. B. Brasiliano (Pan-African) granitic magmatism in the Pajeú-Paraíba Belt, Northeast Brazil: an isotopic and geochronological approach. Precambrian Research. (Submetido).

KOZUCH, M. Isotopic and trace glement geochemistry of Early Neoproterozoic Gneissic and Metavolcanic rocks of the Cariris Velhos of the Borborema Province, Brazil, and their bearing on Tectonic setting. 199 p. 2003. Thesis (Doctor of Philosophy) - Department of Geology, University of Kansas, Lawrence, USA, 2003.

MEDEIROS, V. C.; SIAL, A. N.; FERREIRA, V. P. O Batólito de Teixeira, Paraíba, NE do Brasil: petrologia e geoquímica. In: SIMPÓSIO DE GEOLOGIA DO NORDESTE, 16., 1995, Recife. Atas... Recife: Sociedade Brasileira de Geologia-Núcleo NE, 1995. Boletim n. 14, v. 1, p. 324-328. 
PESSOA, R. J. R. Mecanismos de alojamento e construção do Batólito Granítico Neoproterozóico de Tavares-Estado da Paraíba - nordeste do Brasil. 2001. 210 p. Tese (Doutorado) - Centro de Geociências e Tecnologia, Universidade Federal de Pernambuco, Recife, 2001.

SANTOS, E. J. O Complexo Granítico Lagoa das Pedras: acresção e colisão na região de Floresta (Pernambuco). 1995. 219 p. Tese (Doutorado) - Instituto de Geociências, Universidade de São Paulo, São Paulo, 1995.

SANTOS, E. J.; FERREIRA, C. A.; SILVA JUNIOR, J. M. F. Geologia e recursos minerais do Estado da Paraíba: texto explicativo dos mapas geológicos e de recursos minerais do Estado da Paraíba. Recife: CPRM; Serviço Geológico do Brasil, 2002. 142 p. +2 mapas.

SANTOS, E. J.; MEDEIROS, W. C. Constraints from granitic plutonism on Proterozoic crustal growth of the Transverse Zone, Borborema Province, Northeast Brazil. Revista Brasileira de Geociencias,v. 29, n. 1, p. 73-84, 1999.

SANTOS, E. J.; NUTMANN, A. P.; BRITO NEVES, B. B. Idades SHRIMP U_PB do Complexo Sertânia: implicações sobre a evolução tectônica da Zona Transversal, Província Borborema. Geologia USP, v. 4, n. 1, p. 1-12, 2003.

SANTOS, E. J.; OLIVEIRA, R. G.; PAIVA, I. P. Terrenos no domínio transversal da província Borborema: controle sobre acresção e retrabalhamento crustais ao sul do lineamento Patos. In: SIMPÓSIO DE GEOLOGIA DO NORDESTE, 17., 1997, Fortaleza. Resumos expandidos. Fortaleza: Sociedade Brasileira de Geologia-Núcleo NE, 1997. Boletim n. 15, p. 141-144.

SIAL, A. N. Granite-types in Northeast Brazil, current knowledge. Revista Brasileira de Geociências, v. 16, n. 1, p. 10-20, 1986 .

SIAL, A. N.; FERREIRA, V. P.; SANTOS, E. J. Magmatic epidote-bearing granitoids and ultrapotassic magmatism of the Borborema Province, Northeast Brazil. In: INTERNATIONAL SYMPOSIUM ON GRANITES AND ASSOCIATED MINERALIZATIONS, 2., 1997, Salvador. Excursion guide. Salvador: Companhia Baiana de Pesquisa Mineral, 1997. p. 35-53.

SIAL, A. N.; FERREIRA, V. P.; MARIANO, G. Proterozoic granitoide, western Pernambuco and Paraíba states, Northeast Brazil. In: INTERNATIONAL SYMPOSIUM ON GRANITES AND ASSOCIATED MINERALIZATIONS, 1 , 1987, Salvador. Excursion guides. Salvador: Secretaria das
Minas e Energia do Estado da Bahia, 1987. p. 9-32.

SIAL,A. N.; SILVAFILHO, A. F.; GUIMARÃES, I. P. Mineral chemistry of the Late Precambrian Salgueiro Batholith, State of Pernambuco, Northeast Brazil. Anais da Academia Brasileira de Ciências, v. 55, n. 1, p. 55-69, 1983.

SILVA FILHO, A. F. Petrologia e geoquímica do batólito de Salgueiro - PE. Recife, 1982. 222 p. Dissertação (Mestrado) - Departamento de Geologia, Centro de Tecnologia da Universidade Federal de Pernambuco, 1982.

SILVA FILHO, A. F. Shoshonitic and ultrapotassic intrusive suites in the Piancó-Alto Brígida Belt, Pernambuco State, Brazil. Londres, 1989. 422 p. Tese (Doutorado) - Imperial College of Science Technology and Medicine, 1892.

SILVAFILHO, A.; GUIMARÃES, I. P.; THOMPSON, R. N. Shoshonitic and ultrapotassic Proterozoic intrusive suites in the Cachoeirinha-Salgueiro belt, NE Brazil: a transition from collisional to post-collisional magmatism. Precambrian Research, v. 62, p.323-342, 1993.

SILVA FILHO, A. F.; GUIMARÃES, I. P. Geologia e geoquímica do plutão shoshonítico de Terra Nova, evidências do magmatismo proterozóico de pressão média na Província Borborema. Revista Brasileira de Geociências, v. 21, n. 1, p. 51-59, 1991.

TROMPETTE, R. Geology of Western Gondwana (2000500Ma)./Rotterdam/Brookfields: A. Balkema, 1994.350 p.

VAN SCHMUS, W. R.; BRITO NEVES, B. B.; HACKSPACHER, P.; BABINSKI, M. U/Pb and $\mathrm{Sm} / \mathrm{Nd}$ geochronologic studies of the eastern Borborema Province, Northeastern Brazil: initial conclusions. Journal of South American Earth Sciences, v. 8, n. 3/4, p. 267-288, 1995. 